Prepared in cooperation with the TAHOE REGIONAL PLANNING AGENCY

\title{
Ground-Water Reconnaissance of the Bijou Creek Watershed, South Lake Tahoe, California, June-October 2003
}

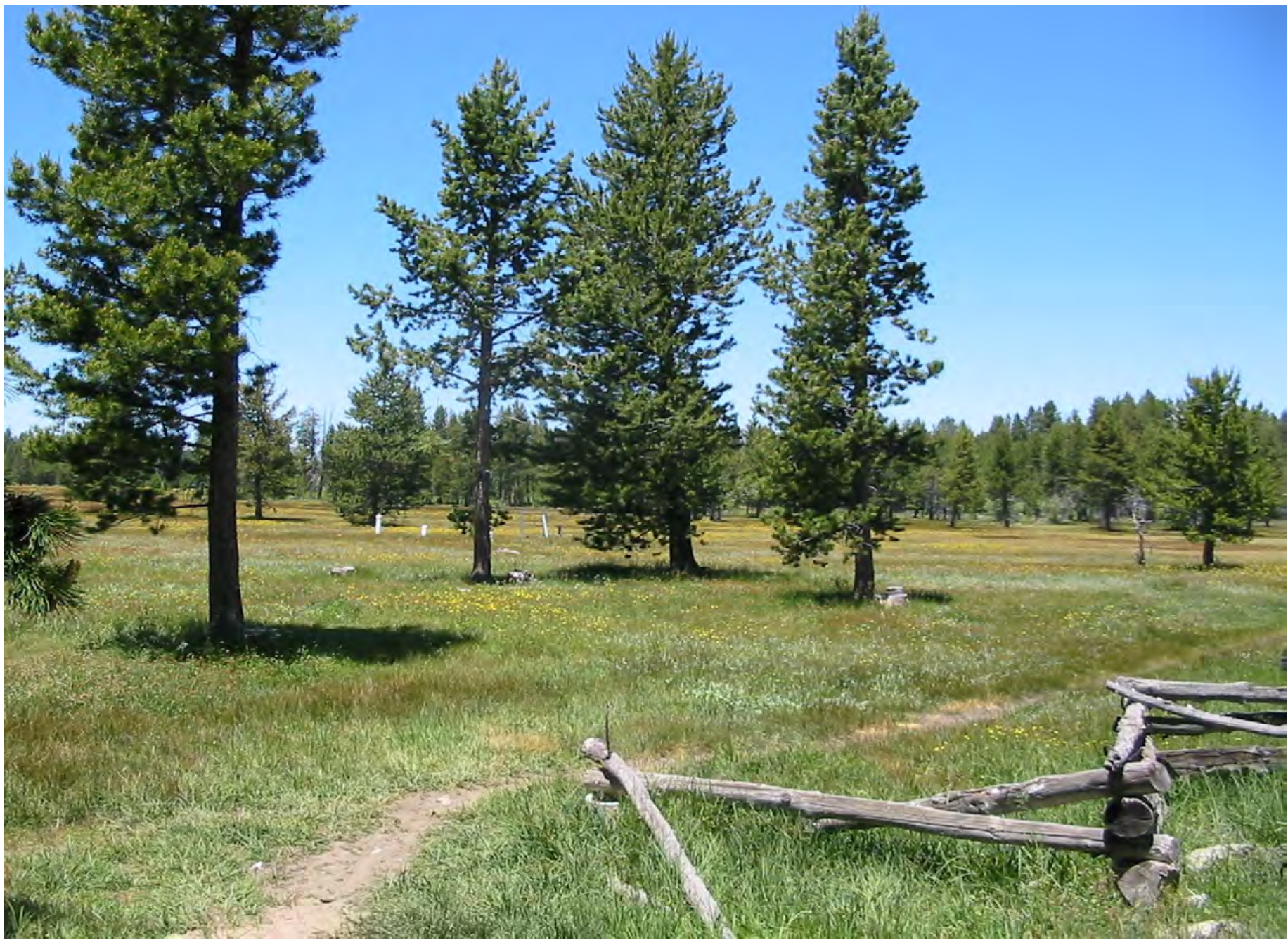

Open-File Report 2005-1329 
COVER: View of meadow in Bijou Creek area, South Lake Tahoe, California. Photograph taken by Kip Allander 2003 


\section{Ground-Water Reconnaissance of the Bijou Creek Watershed, South Lake Tahoe, California, June-October 2003}

By Kip K. Allander

Prepared in cooperation with the

TAHOE REGIONAL PLANNING AGENCY

Open-File Report 2005-1329 


\title{
U.S. Department of the Interior \\ Gale A. Norton, Secretary
}

\section{U.S. Geological Survey \\ P. Patrick Leahy, Acting Director}

U.S. Geological Survey, Carson City, Nevada: 2005

For sale by U.S. Geological Survey, Information Services

Box 25286, Denver Federal Center

Denver, CO 80225

For more information about the USGS and its products:

Telephone: 1-888-ASK-USGS

World Wide Web: http://www.usgs.gov/

\begin{abstract}
Any use of trade, product, or firm names in this publication is for descriptive purposes only and does not imply endorsement by the U.S. Government.

Although this report is in the public domain, permission must be secured from the individual copyright owners to reproduce any copyrighted materials contained within this report.
\end{abstract}

For additional information contact:

Director

USGS, Nevada Water Science Center

333 W. Nye Lane, Room 203

Carson City, NV 89706-0866

email: GS-W-NVpublic-info@usgs.gov

http://nevada.usgs.gov 


\section{Contents}

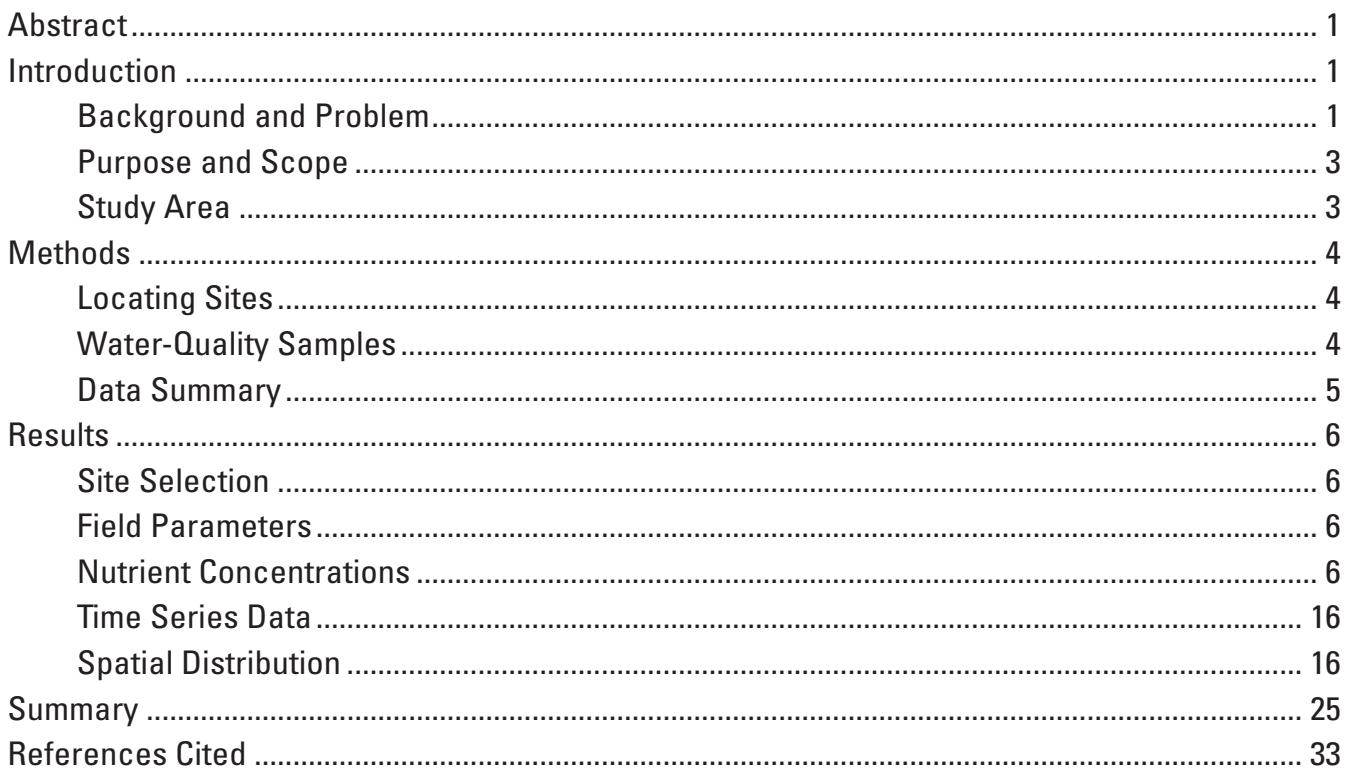

\section{Figures}

Figure 1. Map showing location of Bijou Creek watershed in South Lake Tahoe, California ........... 2

Figure 2. Map showing measured water levels in the Bijou Creek watershed.............................. 11

Figure 3. Boxplots showing distributions of water temperature, $\mathrm{pH}$, and specific conductance in samples from Bijou Creek watershed ground water during the summer of 2003 and in samples from the Lake Tahoe Interagency Monitoring Program ground-water network during the summer of 2002

Figure 4. Boxplots showing distributions of filtered ammonia $\left(\mathrm{NH}_{4}\right)$, nitrate $\left(\mathrm{NO}_{3}\right)$, organic nitrogen plus ammonia (DKN), orthophosphate (DOP), phosphorus (DP), and biologically-available iron (DFe) concentrations in samples from Bijou Creek watershed ground water during the summer of 2003 and in samples from the Lake Tahoe Interagency Monitoring Program ground-water network during the summer of 2002

Figure 5. Time series plots of water temperature, $\mathrm{pH}$, and specific conductance .......................... 17

Figure 6. Time series plots of filtered ammonia $\left(\mathrm{NH}_{4}\right)$, nitrate $\left(\mathrm{NO}_{3}\right)$, and organic nitrogen plus ammonia (DKN) concentrations

Figure 7. Time series plots of orthophosphate (DOP), phosphorus (DP), and biologicallyavailable iron (DFe) concentrations

Figure 8. Map showing field measured values in the Bijou Creek watershed, California, for water temperature, $\mathrm{pH}$, and specific conductance.

Figure 9. Map showing nutrient concentrations in the Bijou Creek watershed measured during the summer of 2003, for ammonia, nitrate, organic nitrogen plus ammonia, orthophosphate, phosphorus, and biologically-available iron. 


\section{Tables}

Table 1. Selected characteristics and water levels of ground-water sites in Bijou Creek watershed, California, June-0ctober 2003.

Table 2. Selected characteristics of surface-water site in Bijou Creek watershed, California, June-October 2003.

Table 3. Statistical summary of water-quality data for ground-water sites sampled in Bijou Creek watershed, California, June-0ctober 2003 and for Lake Tahoe Interagency

Monitoring Program ground-water network sampled during summer of 2002

Table 4. Water-quality data and summary statistics on depth stratified water-quality data for ground-water sites sampled in Bijou Creek watershed, California, June-0ctober 2003.

Table 5. Time series water-quality data and trend-test results for ground-water sites 19 and 21 in the Bijou Creek watershed, California. 18

Table 6. Water-quality data for surface-water site sampled in Bijou Creek watershed, California, during summer of 2003.

\section{Conversion Factors, Datums, and Abbreviated Water-Quality Units}

\begin{tabular}{rcl}
\hline \multicolumn{1}{c}{ Bultiply } & By & \multicolumn{1}{c}{ To obtain } \\
\hline & Length & \\
inch (in.) & 25.4 & millimeter $(\mathrm{mm})$ \\
foot $(\mathrm{ft})$ & 0.3048 & meter $(\mathrm{m})$ \\
mile $(\mathrm{mi})$ & 1.609 & kilometer $(\mathrm{km})$ \\
\hline & Area & \\
square mile $\left(\mathrm{mi}^{2}\right)$ & 2.590 & square kilometer $\left(\mathrm{km}^{2}\right)$ \\
\hline & Volume & \\
gallon $(\mathrm{gal})$ & 3.785 & liter $(\mathrm{L})$ \\
\hline & Flow rate & \\
cubic foot per second $(\mathrm{ft} / \mathrm{s})$ & 0.02832 & cubic meter per second $\left(\mathrm{m}^{3} / \mathrm{s}\right)$ \\
foot per year $(\mathrm{ft} / \mathrm{yr})$ & 0.3048 & meter per year $(\mathrm{m} / \mathrm{yr})$ \\
gallon per minute $(\mathrm{gal} / \mathrm{min})$ & 0.06309 & liter per second $(\mathrm{L} / \mathrm{s})$ \\
\hline
\end{tabular}

Temperature: Degrees Celsius $\left({ }^{\circ} \mathrm{C}\right)$ can be converted to degrees Fahrenheit $\left({ }^{\circ} \mathrm{F}\right)$ as follows:

$$
{ }^{\circ} \mathrm{F}=\left(1.8 \times{ }^{\circ} \mathrm{C}\right)+32
$$

Vertical coordinate information: The "North American Vertical Datum of 1988 (NAVD 88)" is the vertical coordinate system used throughout this report.

Horizontal coordinate information: The "North American Datum of 1983 (NAD 83)" is the horizontal coordinate system used throughout this report.

Altitude: As used in this report, refers to distance above the vertical datum. The vertical datum in the report is mean sea level.

Sea level: In this report, "sea level" refers to the mean sea level as derived from a general adjustment of the first-order leveling networks of the United States and Canada with reference to the NAVD 88

\section{Abbreviated Water-Quality Units Used in this Report:}

$\mu \mathrm{g} / \mathrm{L}$ (microgram per liter)

$\mu \mathrm{m}$ (micrometer)

$\mu \mathrm{S} / \mathrm{cm}$ (microsiemens per centimeter) $\mu \mathrm{S} / \mathrm{cm} / \mathrm{yr}$ (microsiemens per centimeter per year) $\mathrm{mg} / \mathrm{L}$ (milligram per liter) $\mathrm{mg} / \mathrm{L} / \mathrm{yr}$ (milligram per liter per year) 


\title{
Ground-Water Reconnaissance of the Bijou Creek Watershed, South Lake Tahoe, California, June-October 2003
}

\author{
By Kip K. Allander
}

\section{Abstract}

A ground-water reconnaissance study of the Bijou Creek watershed in South Lake Tahoe, California was done during the summer and early fall of 2003. This study provides basic hydrologic data for a region in the Lake Tahoe Basin in which a continuing loss of lake clarity is occurring in the nearshore zone of Lake Tahoe. Wells, springs, and a surface-water site were located and basic hydrologic data were collected. Water levels were measured and water samples were collected and analyzed for nutrients. Measurements of water temperature, specific conductance, and $\mathrm{pH}$ were made at all ground-water sites where possible and at one surface-water site.

Organic nitrogen plus ammonia, ammonia, and biologically-available iron concentrations generally were greater in the ground water in the Bijou Creek watershed than those observed in ground water elsewhere in the Lake Tahoe Basin. Nitrate concentrations were similar in the two groups. Phosphorus and orthophosphate concentrations generally were lower in the ground water of the Bijou Creek watershed compared to ground water from elsewhere in the Lake Tahoe Basin. Specific conductance and $\mathrm{pH}$ of ground water were similar between the Bijou Creek watershed and the Lake Tahoe Basin, but the temperature of ground water was generally greater in the Bijou Creek watershed.

Nitrate concentrations appeared to increase over time at one of two long-term ground-water sites. Orthophosphate concentration decreased while specific conductance increased at one of the two sites, but no trend was detected at the other site for either parameter. No trends were detected for phosphorus, biologically-available iron, water temperature, or $\mathrm{pH}$ at either of the long-term sites. Trends in ammonia and organic nitrogen plus ammonia concentrations were not evaluated because a majority of the values were below the method detection limits.

There were no obvious spatial distribution patterns for nutrient concentrations or field parameters in the Bijou Creek watershed. The altitude of the ground-water table above sea level generally increased with increasing distance from Lake Tahoe. The altitude of the ground-water table was greater than the altitude of the surface of Lake Tahoe except at one ground- water site which is influenced by a cone of depression around a nearby production well. Ground water in the Bijou Creek watershed discharges to Lake Tahoe and may contribute to the higher than normal turbidity in the area.

\section{Introduction}

\section{Background and Problem}

Lake Tahoe, located in the Sierra Nevada approximately 150 mi east of San Francisco, California, is an outstanding natural resource known for its deep, clear water (fig. 1). Protection of the lake's clarity has become more important in the last 50 years, because clarity has been decreasing at a rate of about $1.0 \mathrm{ft} / \mathrm{yr}$ (Goldman, 2000). Human activity in and around the lake has increased nutrient inputs to Lake Tahoe, which has supported an increase in algal growth and has reduced the clarity of the lake (Goldman, 1988). During the late 1960's and 1970's, primary productivity in Lake Tahoe was primarily limited by nitrogen and iron but gradually shifted to phosphorous limitation in the 1980's (Goldman, 1988).

Nutrients enter the lake from tributary streams, atmospheric deposition, runoff from intervening areas (areas not drained by streams), shoreline erosion, and ground-water inflow (Reuter and others, 1998; Reuter and Miller, 2000). Nutrients from streams and the atmosphere are the best quantified sources of nutrients to Lake Tahoe. Several studies that estimate nutrient inputs from intervening areas, shoreline erosion, and ground-water inflow have recently been completed. Thomas and others (2004) estimated ground-water nutrient fluxes in a nearshore area in the northern part of Lake Tahoe. Adams and others (2004) estimated nutrient loads originating from shoreline erosion around Lake Tahoe for 1938 through 1998. Thodal (1997) estimated the total groundwater inflow and nutrient flux to Lake Tahoe on a basin-wide scale. The U.S. Army Corps of Engineers (USACE) estimated nutrient loads from regionalized ground-water inflow to Lake Tahoe (U.S Army Corps of Engineers, 2003). However, quantifying nutrient loads from ground water originating from more localized areas was beyond the scope of these studies. 

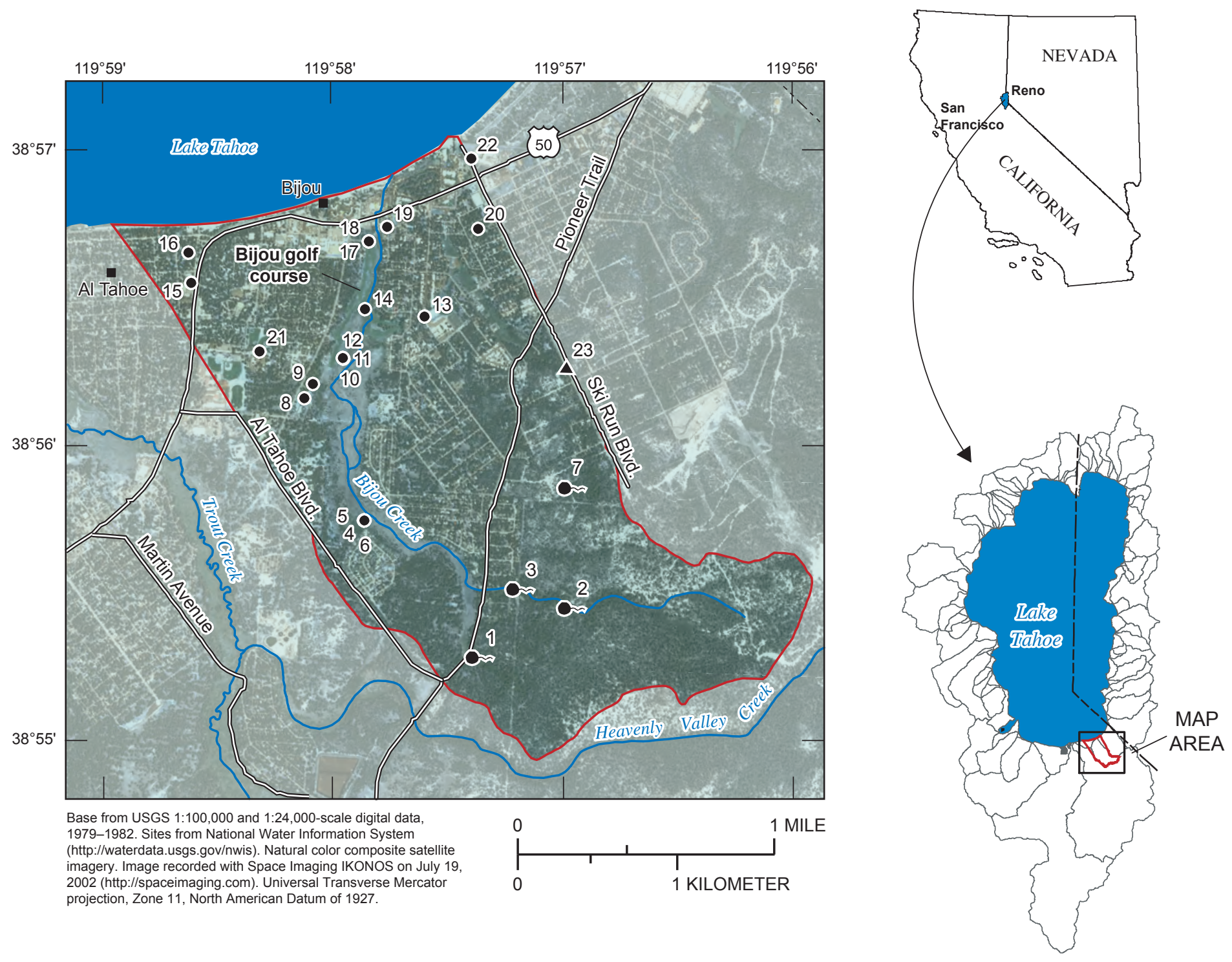

EXPLANATION

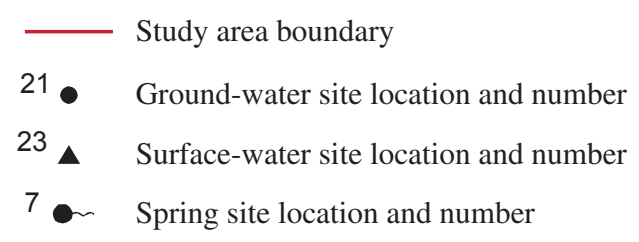

Figure 1. Map showing location of Bijou Creek watershed in South Lake Tahoe, California. 
Several nearshore areas of Lake Tahoe have elevated turbidity compared to the mid-lake environment (Taylor, 2002; Taylor and others, 2004). Taylor (2002) concluded that, although atmospheric deposition may contribute to the lake-wide decline of lake clarity, the nearshore clarity losses are caused by small-scale influences (neighborhood scale). Nearshore clarity losses can be caused by increases of organic material such as algae and increases in suspended sediment either from surface-water inflows or from resuspension of lakebed sediments by wave action. Taylor (2002) hypothesized that elevated algal growth in some nearshore areas may result from ground-water inflow containing nutrients from leaking wastewater lines, disturbed soils, or fertilizers. Taylor and others (2004) concluded that nearshore turbidity in the south shore area was dominated by mineral sources at certain high turbidity periods and by algae during lower turbidity periods. They also suggested that wave action did not have a big influence on turbidity in this area. Taylor (2002) concluded that if the nearshore turbidity issue is mitigated, the mid-lake clarity may improve.

Loeb and others (1986) and Loeb (1987) identified an area of Lake Tahoe in the nearshore zone near the Bijou community of South Lake Tahoe (fig. 1) as having greater contributions of nutrients from ground water than other areas investigated. They found that nitrate concentrations in local ground water increased from the upper parts of the watershed towards the shoreline, and that concentrations were greater at shallow depths. Loeb (1987) concluded this was from nitrate contamination as ground water moved toward Lake Tahoe through developed or disturbed areas of the watershed. The source of these contaminants could be fertilizers, leaking wastewater lines, and increased nitrification following land disturbance (Loeb, 1987).

Rowe and Allander (2000) compared nutrient concentrations in water samples from nine wells in the South Lake Tahoe area with nutrient concentrations from Trout Creek and Upper Truckee River. Concentrations of nutrients generally were greater in ground water than in surface water in the Upper Truckee River and Trout Creek watersheds. This indicated ground water may be an important source of nutrients to Lake Tahoe.

The U.S. Geological Survey (USGS) is currently (2005) investigating ground-water and surface-water exchanges in several areas in South Lake Tahoe. The Cattlemans detention basin study is investigating the influence of infiltration of stormwater runoff in a detention basin on ground-water flow and nutrient discharge to Cold Creek. The Trout Creek study is investigating temporal and spatial variability of groundwater exchange with Trout Creek. These studies are providing important information on dynamic exchange of ground water and streams. This report describes a reconnaissance-level study in the Bijou Creek watershed area that provides additional information on the dynamic exchange of ground water and Lake Tahoe.
Increasingly, studies indicate that a substantial portion of lake clarity problems may be from small inflows of nutrient enriched ground water (Taylor, 2002; Taylor and others, 2004). Small inflows of nutrient enriched ground water may be controllable with environmental mitigation or regulation, making an attractive target for economical application of environmental improvement projects.

Taylor (2002) identified several areas near the shoreline of Lake Tahoe that consistently had elevated turbidity. One of these areas was in South Lake Tahoe near the Bijou Creek watershed (fig. 1), the same area that Loeb and others (1986) and Loeb (1987) identified as having greater ground-water inflow and greater nitrate concentrations than other shoreline areas around Lake Tahoe.

The hypothesis tested in this reconnaissance study is that nutrient concentrations in ground water in the Bijou Creek watershed are greater than in the Lake Tahoe basin in general, and that ground water in the study area flows toward and discharges into Lake Tahoe. Discharge of nutrient-rich ground water to Lake Tahoe might explain why there is elevated turbidity in the nearshore zone of the Bijou Creek watershed area.

\section{Purpose and Scope}

The USGS, in cooperation with the Tahoe Regional Planning Agency (TRPA), began a ground-water study of the Bijou Creek watershed area in late June of 2003. The objective of this study was to characterize ground-water conditions in the study area. Field work for this study was done during late June to mid-October 2003, and included (1) locating ground-water wells, springs, and surface-water sites with flowing water, (2) measuring ground-water levels in wells and springs, and (3) collecting water samples for nutrient analysis and measurement of field parameters. The principle objective of this report is to describe the ground- and surface-water data collected during this study.

\section{Study Area}

The study area includes the entire Bijou Creek watershed as well as the areas from the natural drainage boundary northeast to Ski Run Boulevard, and southwest from a line extending from Al Tahoe Boulevard to Lake Tahoe (fig. 1). The Bijou Creek watershed has a drainage area of $2.35 \mathrm{mi}^{2}$ and a drainage perimeter of $6.99 \mathrm{mi}$ (Cartier and others, 1995). Bijou Creek is $3.3 \mathrm{mi}$ long and is a tributary to Lake Tahoe (Jorgensen and others, 1978). Geology in the study area consists of granitic rock in the steeper mountainous terrain and quaternary lake and fluvial deposits as well as glacial outwash and till along the lower and less steep terrain near Lake Tahoe (Tahoe Regional Planning Agency and U.S. Forest Service, 
1971). A geologic cross section developed by Scott and others (1978) extends between the Trout Creek watershed near the Martin Avenue bridge crossing to Lake Tahoe between the Al Tahoe and Bijou communities. This cross section shows estimated distribution and extent of fine-grained sediments as well as basement rock geometry in and near the study area and an almost continuous band of fined-grained sediments below the surface at an altitude of about 6,200 ft. This indicates that the basement rock slopes toward the Trout Creek watershed.

Land use in the study area is a mixture of residential, recreational, and commercial uses, and undeveloped forest. Undeveloped, natural forest conditions exist in the upper parts (headwaters) of the drainage area. The forest transitions to residential land use and then to commercial land use near Lake Tahoe. Bijou Golf Course is a prominent feature in the lowermiddle part of the drainage basin and along the lower reaches of Bijou Creek (fig. 1).

The Bijou Creek watershed receives between 20 and 35 in. of precipitation a year, with the majority of the precipitation falling during the winter as snow (Crippen and Pavelka, 1970). The field work for this study was done following a winter with less than normal precipitation and relatively low runoff during the spring snowmelt period (Stockton and others, 2003).

\section{Methods}

Data collection consisted of locating wells, springs, and a surface-water site, measuring depth to ground water, collecting water samples for the analysis of nutrient concentrations, and measuring water temperature, specific conductance, and $\mathrm{pH}$.

\section{Locating Sites}

Wells were located by reviewing the USGS GroundWater Site Information (GWSI) database, exchanging information with other government agencies, and by field reconnaissance. Springs were located by examining a 1:24,000 topographic map of the study area and field reconnaissance. Surface-water sites were located by examining the topographic map, information exchange with other government agencies, and field reconnaissance. A surface-water site was established only if flow was observed during the field work in the summer of 2003. Because precipitation for the previous winter was below average, only one surface-water site was located that was flowing during the summer of 2003.

Once a well was located, the following well characteristics were determined: location (latitude, longitude), altitude, well diameter, well depth, screened interval, and depth to water. Whenever possible, a drillers report that was associated with a well was used to determine well construction characteristics. Horizontal location was determined within one second in latitude and longitude using a survey grade Global Positioning System (GPS). Altitude was determined to within one foot using a survey grade GPS. If wells had been located during previous USGS investigations, the physical locations were determined using 1:24,000 topographic maps and were located with less accuracy as compared to wells located using a GPS. Well diameter, well depth, and screened interval were determined from the well drillers report, if available, or were measured in the field, if possible. Depth to water was measured using an engineer's steel tape or an electric indicator tape.

Springs were inspected to document flow conditions and physical characteristics. The spring condition was determined to be either a discharging spring (water is surfacing) or a seeping spring (water is often discharging at the surface, but at time of field sample collection, water level had retreated to within a few tenths of a foot from the land surface). The physical characteristics determined were location (latitude, longitude), land-surface altitude, and depth to water. Depth to water was determined by observation; if water was at the surface, then depth to water was $0 \mathrm{ft}$ below land surface, but if water was below the surface, a small hole was pushed into the spring and depth was estimated (generally less than $0.2 \mathrm{ft}$ below land surface).

Once a surface-water site with flow was located, the following physical characteristics were determined: location (latitude, longitude), altitude, and estimated discharge. Discharge was estimated and not measured because the special equipment required for measuring such small streamflows was unavailable at the time of the site visit.

\section{Water-Quality Samples}

Water-quality samples were collected from most well and spring sites and from the surface-water site. Nutrient concentrations and field parameters (water temperature, specific conductance, and $\mathrm{pH}$ ) were determined for each sample. The following nutrients were analyzed from filtered samples: ammonia as $\mathrm{N}\left(\mathrm{NH}_{4}\right)$, nitrite plus nitrate as $\mathrm{N}\left(\mathrm{NO}_{2}+\mathrm{NO}_{3}\right)$, organic nitrogen plus ammonia as $\mathrm{N}(\mathrm{DKN})$, orthophosphate as $\mathrm{P}$ (DOP), phosphorus as $\mathrm{P}$ (DP), and biologically-available iron as $\mathrm{Fe}(\mathrm{DFe})$. For the purposes of this report, nitrite $\left(\mathrm{NO}_{2}\right)$ concentrations are assumed to be negligible and the measured $\mathrm{NO}_{2}+\mathrm{NO}_{3}$ concentration is assumed to be entirely nitrate $\left(\mathrm{NO}_{3}\right)$. This assumption is based on the finding by Thodal (1997) that $\mathrm{NO}_{2}$ concentrations are generally insignificant in the Lake Tahoe Basin ground water. Biologically-available iron is not the iron content of the water, rather it is the amount of iron available for uptake by algae and is determined using a modified ferrozine method (Hunter and others, 1993). At the surface-water site, organic nitrogen plus ammonia as $\mathrm{N}$ (TKN), and biologically-available iron as Fe (TFe) were analyzed from unfiltered water samples to determine the nutrient content of the particulate fraction. The following parameters were measured onsite from unfiltered samples: water temperature, $\mathrm{pH}$, and specific conductance. 
Water-quality samples were collected from wells by using either a peristaltic pump with silicon tubing or by using existing submersible pumps and discharge points. Three casing volumes of water were pumped from the wells prior to sampling. Samples were collected from the springs by using a quarter-inch stainless steel shallow drive point that was inserted beneath the surface of the spring near the orifice. A minimum of one liter of water was pumped through the drive point and silicon tubing using a peristaltic pump to rinse the sample collection equipment with the native water. A nonisokinetic dip method (Wilde and others, 1999) was used to sample the surface-water site because the stream was too shallow to use a depth integrated approach.

Nutrient samples were filtered through a 0.45 - $\mu$ m capsule filter into amber polyethylene sample bottles that were rinsed three times with the native water. Water temperature was measured by directly flowing water over a liquid-in-glass field thermometer in the shade until the temperature reading was stable. Native water for the remaining field parameters was collected in a one-liter bottle rinsed three times with sample water. Specific conductance and $\mathrm{pH}$ were measured in the field using electronic instruments that were calibrated prior to each sample. Nutrient samples were preserved by chilling to $4^{\circ} \mathrm{C}$ or below and shipped to the laboratories within the required holding period (Hunter and others, 1993). Nutrients were analyzed by the University of California, Davis, Tahoe Research Group (TRG) Limnology Laboratory in Davis and Tahoe City, CA.

Quality control measures were taken to ensure low bias and variability in nutrient and field measurements (water temperature, $\mathrm{pH}$, and specific conductance), and to ensure the data being reported was accurate. Bias in nutrient concentrations introduced through field procedures and laboratory analytical procedures was minimized by using de-ionized water to clean and flush sampling and analytical equipment between sample collections and processing. Long-term measurements of nutrient-free water processed in a similar way and through similar equipment show that this cleaning method is effective at removing nutrient contaminants from sample and laboratory equipment. Bias in nutrient concentrations introduced by laboratory analytical processes was monitored by measuring recovery rates in about 10 percent of environmental samples to which known concentrations of nutrients were added. Variability in nutrient concentrations introduced by laboratory procedures was measured by replicating analyses on approximately 10 percent of all samples. This was done to ensure that variability in analytical results fell within acceptable quality control limits set by the laboratory. The quality of field measurements (water temperature, $\mathrm{pH}$, and specific conductance) was ensured by using calibrated instruments. Water temperature was measured using calibrated liquid-in-glass thermometers. Specific conductance and $\mathrm{pH}$ meters were calibrated using standards that were greater than and less than the field values measured before each measurement. Quality of data reporting was ensured by repeated data reviews by the author, as well as by numerous other internal reviewers.

\section{Data Summary}

Physical characteristics data for ground-water sites and the surface-water site in the Bijou Creek watershed are presented. Nutrient concentration and field measurement data for ground-water sites and the surface-water site in the Bijou Creek watershed also are presented. Maximum, minimum, and median water quality values are analyzed for shallow and deep ground water. Shallow ground water is arbitrarily defined as ground water at depths of less than $18 \mathrm{ft}$ below land surface, and deep ground water is defined as ground water at depths greater than or equal to $18 \mathrm{ft}$ below land surface. A depth of $18 \mathrm{ft}$ was chosen to discriminate shallow from deep ground water because it represents an approximate median depth of the sampled wells.

Summary statistics were computed for nutrient concentration and field measurement data collected from the groundwater sites in the Bijou Creek watershed during the summer of 2003 and from the Lake Tahoe Interagency Monitoring Program (LTIMP) ground-water network sites during the summer of 2002 and are compared in tables and boxplots. It is assumed that the ground-water data from the LTIMP ground-water network represents the general ground-water conditions of the Lake Tahoe Basin. The summary statistics used to characterize the data were sample size, maximum, 90th percentile, 75 th percentile, median, 25 th percentile, 10th percentile, and minimum. Boxplots are used to graphically present the distribution of the data. The "box" of a boxplot defines the central 50 percent of data [the vertical size of the box is also referred to as the interquartile range (IQR)]. The line dividing the box is the median or the 50th percentile. Lines extending below and above the boxes are referred to as "whiskers" and represent the 10th and 90th percentiles, respectively. Data points that are less than the 10th percentile or greater than the 90th percentile (outliers) are not shown in the boxplots.

Procedures for LTIMP ground-water monitoring are the same procedures as those used by Rowe and Allander (2000), and are the same as those used in this study. Locations of LTIMP ground-water sites are presented by Boughton and others (1997). Nutrient and field measurement data for the LTIMP ground-water network are listed by Berris and others (2002).

Two wells in the LTIMP ground-water network (sites 19 and 21; fig. 1) also are located within the Bijou Creek watershed and have nutrient concentration and field measurement data starting in December 1989. These two sites have been sampled approximately once a year since December 1989. These two sites also are included as part of the Bijou Creek watershed ground-water data set. Because these two sites have a significant amount of historical data, trend analysis of the data was possible. Trends in properties are valuable to identify because they can be used to evaluate whether or not certain decisions or actions are improving the properties of interest. The trend tests computed as part of this study only describe the changes in data over the period of record for these two sites. These trends do not suggest future changes and are not 
intended to be used for forecasting future values. The field parameters and nutrient concentration data for these two sites are presented in time series plots (scatter plots of concentrations over time). Linear regression was used to evaluate the time series data for trends. Linear regression results of slope, intercept, probability that slope is significant ( $p$-value), amount of variability of data explained by time $\left(\mathrm{R}^{2}\right)$, and trend test results are summarized for each constituent for both of these sites.

The spatial distribution of nutrient concentrations, field parameters, and water levels are also presented in a series of maps.

\section{Results}

\section{Site Selection}

A total of 23 sites were located within the Bijou Creek study area during the summer of 2003. Twenty-two of these sites were ground-water sites (springs and wells), and one was a surface-water site (tables 1 and 2; fig. 1). Of the 22 ground-water sites, 4 (18 percent) were springs, 11 (50 percent) were observation wells, 3 (14 percent) were irrigation wells, and 4 (18 percent) were production wells or wells historically used as production wells. Of these 22 groundwater sites, 17 were sampled and 13 had water-levels measured during this study. The LTIMP Lake Tahoe ground-water network used for comparison consisted of 31 ground-water sites. Of these 31 sites, 1 (3 percent) was a spring, 10 (32 percent) were observation wells, 1 (3 percent) was an irrigation well, 18 (58 percent) were production wells, and 1 (3 percent) was a domestic well.

The depth of wells in the Bijou Creek watershed ranged from 6.9 to $310 \mathrm{ft}$ below land surface (table 1). Ground-water level altitudes were measured between June 30 and October 21, 2003 and ranged from 6,220 to 6,451 ft (table 1). The stage of Lake Tahoe declined by $1.5 \mathrm{ft}$, from a little less than $6,228 \mathrm{ft}$ to a little more than $6,226 \mathrm{ft}$ over the same period (see graph in fig. 2).

The surface-water site was located near the edge of the study area and was at an altitude of 6,355 ft (site no. 23, fig. 1; table 2). Many other potential surface-water sites, including sites along the main channel of Bijou Creek were inspected for flow but had no streamflow during the study period (June-October 2003).

\section{Field Parameters}

The median water temperature in the Bijou Creek watershed ground water was $11.5^{\circ} \mathrm{C}$, which was $1.5^{\circ} \mathrm{C}$ greater than in the LTIMP ground-water network (table 3, fig. 3). The variability of water temperature in the Bijou Creek water- shed ground water was similar to the variability of water temperature in the LTIMP ground-water network. The IQR (75th percentile minus the 25 th percentile in table 3 ) of water temperature in the Bijou Creek watershed ground water was $3.0^{\circ} \mathrm{C}$, and the IQR of the LTIMP ground-water network was $2.0^{\circ} \mathrm{C}$. Maximum, minimum, and median water temperatures in the shallow ground water in the Bijou Creek watershed area were within $1.5^{\circ} \mathrm{C}$ of the deeper ground water (table 4 ).

The median $\mathrm{pH}$ in the Bijou Creek watershed ground water was 6.7, which was nearly the same as in the LTIMP ground-water network (table 3 , fig. 3 ). The variability of $\mathrm{pH}$ in the Bijou Creek watershed ground water was less than in the LTIMP ground-water network. The IQR of $\mathrm{pH}$ measured in the Bijou Creek watershed ground water was 0.4, which is about one-half the IQR of the LTIMP ground-water network $(1.0 \mathrm{pH}$ units). The maximum $\mathrm{pH}$ in the shallow ground water (6.9) in the Bijou Creek watershed area was substantially less than in the deeper ground water (8.3; table 4); however, median and minimum $\mathrm{pH}$ values for the shallow and deeper ground water were within $0.2 \mathrm{pH}$ units of each other.

The median specific conductance in the Bijou Creek watershed ground water was $150 \mu \mathrm{S} / \mathrm{cm}$, which was similar to the median specific conductance of $172 \mu \mathrm{S} / \mathrm{cm}$ in the LTIMP ground-water network (table 3, fig. 3). The variability of specific conductance in the Bijou Creek watershed ground water was nearly identical to the specific conductance variability in the LTIMP ground-water network. The IQR of specific conductance in the Bijou Creek watershed ground water was $104 \mu \mathrm{S} / \mathrm{cm}$, and the IQR of the LTIMP ground-water network was $100 \mu \mathrm{S} / \mathrm{cm}$. Maximum specific conductance in the shallow ground water $(415 \mu \mathrm{S} / \mathrm{cm})$ of the Bijou Creek watershed was less than in the deeper ground water $(490 \mu \mathrm{S} / \mathrm{cm}$; table 4$)$; however, median and minimum specific conductance values for the shallow and deeper ground water were within $20 \mu \mathrm{S} / \mathrm{cm}$ of each other.

\section{Nutrient Concentrations}

The median $\mathrm{NH}_{4}$ concentration was $0.031 \mathrm{mg} / \mathrm{L}$ in the Bijou Creek watershed ground water, which was about 5 times greater than the median $\mathrm{NH}_{4}$ concentration in the LTIMP ground-water network of $0.006 \mathrm{mg} / \mathrm{L}$ (table 3, fig. 4). The variability of $\mathrm{NH}_{4}$ concentrations in the Bijou Creek watershed ground water, as measured with IQR, was greater than in the LTIMP ground-water network. The IQR of the $\mathrm{NH}_{4}$ concentrations measured in the Bijou Creek watershed ground water was $0.018 \mathrm{mg} / \mathrm{L}$, which was nearly double the IQR of the LTIMP ground-water network. The IQR for the LTIMP sites is between $0.008 \mathrm{mg} / \mathrm{L}$ and $0.011 \mathrm{mg} / \mathrm{L}$ and is not precisely known because the 25 th percentile is $<0.003 \mathrm{mg} / \mathrm{L}$. The maximum $\mathrm{NH}_{4}$ concentration in the deeper ground water $(0.120 \mathrm{mg} / \mathrm{L})$ of the Bijou Creek watershed area was more than two times greater than in the shallow ground water $(0.048$ $\mathrm{mg} / \mathrm{L}$; table 4); however, median and minimum $\mathrm{NH}_{4}$ concentrations for the deep and shallow ground water were similar. 
Table 1. Selected characteristics and water levels of ground-water sites in Bijou Creek watershed, California, June-0ctober 2003.

Land-surface altitude uncertainties: $<10$ feet, altitudes were determined from survey grade GPS; $\geq 10$ feet, altitudes determined from topographic map with uncertainty being + or - one-half contour interval. Site type and water use: D, discontinued production well; I, irrigation well; O, observation well; P, production well; S, unused spring.

Site status: $\mathrm{P}$, well being pumped; $\mathrm{R}$, well pumped recently; $\mathrm{S}$, site is a spring and water level is at or slightly below land surface.

Method: T, steel tape; V, calibrated electric tape; O, observed in field.

[Symbols: --, not determined; >, greater than]

\begin{tabular}{|c|c|c|c|c|c|c|c|c|c|c|c|c|}
\hline \multirow[b]{2}{*}{$\begin{array}{c}\text { Site } \\
\text { no. and } \\
\text { depth } \\
\text { desig- } \\
\text { nation }{ }^{1} \\
\text { (fig. 1) }\end{array}$} & \multirow[b]{2}{*}{$\begin{array}{c}\text { USGS } \\
\text { site } \\
\text { identification } \\
\text { number }^{2}\end{array}$} & \multirow[b]{2}{*}{$\begin{array}{l}\text { Latitude and } \\
\text { longitude }^{3}\end{array}$} & \multirow[b]{2}{*}{ Station name } & \multirow{2}{*}{$\begin{array}{l}\text { Land- } \\
\text { surface } \\
\text { altitude } \\
\text { (feet } \\
\text { above } \\
\text { sea } \\
\text { level) }\end{array}$} & \multirow{2}{*}{$\begin{array}{l}\text { Land- } \\
\text { surface } \\
\text { altitude } \\
\text { uncer- } \\
\text { tainty } \\
\text { (+ or } \\
\text { - feet) } \\
\end{array}$} & \multirow[b]{2}{*}{$\begin{array}{l}\text { Casing } \\
\text { diameter } \\
\text { (inches) }\end{array}$} & \multirow[b]{2}{*}{$\begin{array}{c}\text { Total } \\
\text { depth } \\
\text { (feet be- } \\
\text { low land } \\
\text { surface) }\end{array}$} & \multirow[b]{2}{*}{$\begin{array}{c}\text { Open } \\
\text { interval } \\
\text { (feet be- } \\
\text { low land } \\
\text { surface) }\end{array}$} & \multicolumn{4}{|c|}{ Measured water level } \\
\hline & & & & & & & & & $\begin{array}{c}\text { Date } \\
\text { measured }\end{array}$ & $\begin{array}{c}\text { Depth } \\
\text { (feet be- } \\
\text { low land } \\
\text { surface) }\end{array}$ & $\begin{array}{c}\text { Altitude } \\
\text { (feet } \\
\text { above } \\
\text { sea } \\
\text { level) }\end{array}$ & $\begin{array}{c}\text { Site } \\
\text { type and } \\
\text { use/site } \\
\text { status/ } \\
\text { method }\end{array}$ \\
\hline $1 \mathrm{~s}$ & 385517119571801 & $\begin{array}{l}385517.4 \\
1195718.3\end{array}$ & $\begin{array}{l}\text { BIJOU } \\
\text { SUBSURFACE } \\
\text { SITE NO. } 3\end{array}$ & 6,353 & 2 & -- & -- & -- & -- & -- & -- & S/--/-- \\
\hline $2 s^{4}$ & 385529119565501 & $\begin{array}{l}385529 \\
1195655\end{array}$ & $\begin{array}{l}\text { BIJOU CREEK } \\
\text { SPRING NO. } 1\end{array}$ & 6,451 & 2 & -- & -- & -- & $07-25-2003$ & 0 & 6,451 & S/--/O \\
\hline $3 s^{4}$ & 385532119570901 & $\begin{array}{l}385532 \\
1195709\end{array}$ & $\begin{array}{l}\text { BIJOU CREEK } \\
\text { SUBSURFACE } \\
\text { SITE NO. } 2\end{array}$ & 6,373 & 5 & -- & -- & -- & -- & -- & -- & S/--/-- \\
\hline $4 \mathbf{d}^{4}$ & 385544119575101 & $\begin{array}{l}385543.71 \\
1195750.60\end{array}$ & MW1D & $6,259.4$ & 0.5 & 4 & 20.9 & -- & $07-01-2003$ & 7.5 & $6,251.9$ & $\mathrm{O} /--/ \mathrm{V}$ \\
\hline $5 \mathrm{~s}$ & 385544119575102 & $\begin{array}{l}385543.67 \\
1195750.53\end{array}$ & MW1S & $6,259.7$ & 0.5 & 4 & 8.1 & -- & -- & -- & -- & O/--/-- \\
\hline $6 s^{4}$ & 385544119575103 & $\begin{array}{l}385543.65 \\
1195750.43\end{array}$ & MW1M & $6,259.5$ & 0.5 & 4 & 8.2 & -- & $07-01-2003$ & 5.7 & $6,253.8$ & $\mathrm{O} /--/ \mathrm{V}$ \\
\hline $7 \mathrm{~s}$ & 385553119565401 & $\begin{array}{l}385553 \\
1195657\end{array}$ & $\begin{array}{l}\text { POWERLINE } \\
\text { ROAD TRAIL } \\
\text { SPRING NO. } 1\end{array}$ & $6,499.5$ & 0.5 & -- & -- & -- & $07-25-2003$ & 0 & $6,499.5$ & $\mathrm{~S} /--/ \mathrm{O}$ \\
\hline
\end{tabular}




\begin{tabular}{|c|c|c|c|c|c|c|c|c|c|c|c|c|}
\hline \multirow[b]{2}{*}{$\begin{array}{c}\text { Site } \\
\text { no. and } \\
\text { depth } \\
\text { desig- } \\
\text { nation } \\
\text { (fig. 1) }\end{array}$} & \multirow[b]{2}{*}{$\begin{array}{c}\text { USGS } \\
\text { site } \\
\text { identification } \\
\text { number }^{2}\end{array}$} & \multirow[b]{2}{*}{$\begin{array}{l}\text { Latitude and } \\
\text { longitude }^{3}\end{array}$} & \multirow[b]{2}{*}{ Station name } & \multirow[b]{2}{*}{$\begin{array}{c}\text { Land- } \\
\text { surface } \\
\text { altitude } \\
\text { (feet } \\
\text { above } \\
\text { sea } \\
\text { level) }\end{array}$} & \multirow[b]{2}{*}{$\begin{array}{c}\text { Land- } \\
\text { surface } \\
\text { altitude } \\
\text { uncer- } \\
\text { tainty } \\
\text { (+ or } \\
\text { - feet) }\end{array}$} & \multirow[b]{2}{*}{$\begin{array}{l}\text { Casing } \\
\text { diameter } \\
\text { (inches) }\end{array}$} & \multirow[b]{2}{*}{$\begin{array}{c}\text { Total } \\
\text { depth } \\
\text { (feet be- } \\
\text { low land } \\
\text { surface) }\end{array}$} & \multirow[b]{2}{*}{$\begin{array}{c}\text { Open } \\
\text { interval } \\
\text { (feet be- } \\
\text { low land } \\
\text { surface) }\end{array}$} & \multicolumn{4}{|c|}{ Measured water level } \\
\hline & & & & & & & & & $\begin{array}{c}\text { Date } \\
\text { measured }\end{array}$ & $\begin{array}{c}\text { Depth } \\
\text { (feet be- } \\
\text { low land } \\
\text { surface) }\end{array}$ & $\begin{array}{c}\text { Water- } \\
\text { level } \\
\text { altitude } \\
\text { (feet } \\
\text { above } \\
\text { sea } \\
\text { level) }\end{array}$ & $\begin{array}{c}\text { Site } \\
\text { type and } \\
\text { use/site } \\
\text { status/ } \\
\text { method }\end{array}$ \\
\hline $8 \mathbf{d}^{4}$ & 385608119580801 & $\begin{array}{l}385607.79 \\
1195808.23\end{array}$ & HHC-NEW & $6,267.6$ & 0.1 & 6 & 130 & $90-115$ & -- & -- & -- & I/P/-- \\
\hline $9 \mathbf{d}^{4}$ & 385611119580601 & $\begin{array}{l}385610.77 \\
1195806.26\end{array}$ & HHC-OLD & 6,269 & 0.5 & -- & $>20$ & -- & -- & -- & -- & $\mathrm{I} / \mathrm{P} /--$ \\
\hline $10 \mathbf{d}^{4}$ & 385616119575901 & $\begin{array}{l}385616.32 \\
1195758.74\end{array}$ & MW2D & $6,246.1$ & 0.5 & 4 & 32 & -- & $\begin{array}{l}06-30-2003 \\
08-05-2003\end{array}$ & $\begin{array}{r}9.31 \\
10.91\end{array}$ & $\begin{array}{l}6,236.8 \\
6,235.2\end{array}$ & $\begin{array}{l}\mathrm{O} /--/ \mathrm{V} \\
\mathrm{O} /--/ \mathrm{T}\end{array}$ \\
\hline $11 \mathrm{~s}^{4}$ & 385616119575902 & $\begin{array}{l}385616.39 \\
1195758.81\end{array}$ & MW2SA & $6,245.9$ & 0.5 & 4 & 9.3 & -- & $\begin{array}{l}06-30-2003 \\
08-05-2003\end{array}$ & $\begin{array}{l}6.25 \\
7.9\end{array}$ & $\begin{array}{l}6,239.6 \\
6,238.0\end{array}$ & $\begin{array}{l}\mathrm{O} /--/ \mathrm{V} \\
\mathrm{O} /--/ \mathrm{T}\end{array}$ \\
\hline $12 \mathrm{~s}$ & 385616119575903 & $\begin{array}{l}385616.45 \\
1195758.86\end{array}$ & MW2SB & $6,245.5$ & 0.5 & 4 & 8 & -- & 07-08-2003 & 6.46 & $6,239.0$ & $\mathrm{O} /--/ \mathrm{T}$ \\
\hline $13 \mathbf{d}^{4}$ & 385626119573501 & $\begin{array}{l}385626 \\
1195738\end{array}$ & $\begin{array}{l}\text { SLTPUD - } \\
\text { BIJOU }\end{array}$ & 6,259 & 10 & 12.75 & 310 & $245-290$ & 06-06-1990 & 35 & 6,224 & $\mathrm{I} / \mathrm{R} /--$ \\
\hline $14 d^{4}$ & 385627119575401 & $\begin{array}{l}385626.72 \\
1195753.90\end{array}$ & MW4 & $6,238.8$ & 0.5 & 4 & 20 & -- & $\begin{array}{l}07-01-2003 \\
08-04-2003\end{array}$ & $\begin{array}{l}4.25 \\
5.49\end{array}$ & $\begin{array}{l}6,234.6 \\
6,233.3\end{array}$ & $\begin{array}{l}\mathrm{O} /--/ \mathrm{V} \\
\mathrm{O} /--/ \mathrm{V}\end{array}$ \\
\hline $15 \mathbf{d}^{4}$ & 385630119584001 & $\begin{array}{l}385629.64 \\
1195839.70\end{array}$ & TALLAC & $6,261.6$ & 0.1 & -- & 41.9 & -- & -- & -- & -- & O/--/-- \\
\hline $16 \mathrm{~d}$ & 385636119583701 & $\begin{array}{l}385635.8 \\
1195840.9\end{array}$ & $\begin{array}{l}\text { TIMBERLAKE } \\
\text { INN }\end{array}$ & $6,258.2$ & 0.1 & 8 & 97 & -- & $\begin{array}{l}09-19-1996 \\
10-21-2003\end{array}$ & 38.1 & $\begin{array}{c}-- \\
6,220.1\end{array}$ & $\begin{array}{l}\mathrm{P} / \mathrm{P} /-- \\
\mathrm{D} /--/ \mathrm{T}\end{array}$ \\
\hline $17 \mathrm{~d}^{4}$ & 385641119575401 & $\begin{array}{l}385640.54 \\
1195754.08\end{array}$ & MW3D & $6,234.1$ & 0.5 & 4 & 18 & -- & 07-01-2003 & 6.08 & $6,228.0$ & $\mathrm{O} /--/ \mathrm{V}$ \\
\hline $18 s^{4}$ & 385641119575402 & $\begin{array}{l}385640.53 \\
1195754.17\end{array}$ & MW3S & $6,234.5$ & 0.5 & 4 & 6.9 & -- & $\begin{array}{l}07-01-2003 \\
08-06-2003\end{array}$ & $\begin{array}{l}2.62 \\
3.76\end{array}$ & $\begin{array}{l}6,231.9 \\
6,230.7\end{array}$ & $\begin{array}{l}\mathrm{O} /--/ \mathrm{V} \\
\mathrm{O} /--/ \mathrm{T}\end{array}$ \\
\hline $19 \mathrm{~d}^{4}$ & 385644119574601 & $\begin{array}{l}385644 \\
1195750\end{array}$ & $\begin{array}{l}\text { BEVERLY } \\
\text { LODGE }\end{array}$ & 6,239 & 20 & -- & 76 & -- & $06-22-1960$ & 10 & 6,229 & P/R/-- \\
\hline
\end{tabular}


Table 1. Selected characteristics and water levels of ground-water sites in Bijou Creek watershed, California, June-0ctober 2003--Continued

\begin{tabular}{|c|c|c|c|c|c|c|c|c|c|c|c|c|}
\hline \multirow[b]{2}{*}{$\begin{array}{c}\text { Site } \\
\text { no. and } \\
\text { depth } \\
\text { desig- } \\
\text { nation } \\
\text { (fig. 1) }\end{array}$} & \multirow[b]{2}{*}{$\begin{array}{c}\text { USGS } \\
\text { site } \\
\text { identification } \\
\text { number }^{2}\end{array}$} & \multirow[b]{2}{*}{$\begin{array}{l}\text { Latitude and } \\
\text { longitude }^{3}\end{array}$} & \multirow[b]{2}{*}{ Station name } & \multirow[b]{2}{*}{$\begin{array}{l}\text { Land- } \\
\text { surface } \\
\text { altitude } \\
\text { (feet } \\
\text { above } \\
\text { sea } \\
\text { level) }\end{array}$} & \multirow[b]{2}{*}{$\begin{array}{l}\text { Land- } \\
\text { surface } \\
\text { altitude } \\
\text { uncer- } \\
\text { tainty } \\
\text { (+ or } \\
\text { - feet) }\end{array}$} & \multirow[b]{2}{*}{$\begin{array}{c}\text { Casing } \\
\text { diameter } \\
\text { (inches) }\end{array}$} & \multirow[b]{2}{*}{$\begin{array}{c}\text { Total } \\
\text { depth } \\
\text { (feet be- } \\
\text { low land } \\
\text { surface) }\end{array}$} & \multirow[b]{2}{*}{$\begin{array}{l}\text { Open } \\
\text { interval } \\
\text { (feet be- } \\
\text { low land } \\
\text { surface) }\end{array}$} & \multicolumn{4}{|c|}{ Measured water level } \\
\hline & & & & & & & & & $\begin{array}{c}\text { Date } \\
\text { measured }\end{array}$ & $\begin{array}{l}\text { Depth } \\
\text { (feet be- } \\
\text { low land } \\
\text { surface) }\end{array}$ & $\begin{array}{c}\text { Water- } \\
\text { level } \\
\text { altitude } \\
\text { (feet } \\
\text { above } \\
\text { sea } \\
\text { level) }\end{array}$ & $\begin{array}{c}\text { Site } \\
\text { type and } \\
\text { use/site } \\
\text { status/ } \\
\text { method }\end{array}$ \\
\hline $20 \mathbf{d}^{4}$ & 385646119571901 & $\begin{array}{l}385644.5 \\
1195725.9\end{array}$ & ALDER & 6,260 & 1 & 8 & $>20$ & -- & $\begin{array}{l}09-17-1996 \\
09-07-2003\end{array}$ & -- & $\begin{array}{l}-- \\
--\end{array}$ & $\begin{array}{l}\text { P/P/-- } \\
\text { P/P/-- }\end{array}$ \\
\hline $21 \mathbf{d}^{4}$ & 385651119581701 & $\begin{array}{l}385617 \\
1195821\end{array}$ & AL TAHOE & 6,264 & 20 & 12 & 125 & -- & $\begin{array}{l}09-28-1957 \\
03-18-1992 \\
06-28-1995 \\
11-22-1996\end{array}$ & $\begin{array}{l}30 \\
33.27 \\
-- \\
32.06\end{array}$ & $\begin{array}{r}6,234 \\
6,231 \\
-- \\
6,232\end{array}$ & $\begin{array}{l}\mathrm{P} / \mathrm{R} /-- \\
\mathrm{P} / \mathrm{R} / \mathrm{T} \\
\mathrm{P} / \mathrm{P} /-- \\
\mathrm{P} / \mathrm{R} / \mathrm{T}\end{array}$ \\
\hline $22 \mathbf{s}^{4}$ & 385659119572901 & $\begin{array}{l}385658.70 \\
1195728.78\end{array}$ & EVR-1 & $6,236.5$ & 0.1 & 2 & 12.8 & $4.5-12.8$ & $10-21-2003$ & 7.77 & $6,228.8$ & $\mathrm{O} /--/ \mathrm{T}$ \\
\hline
\end{tabular}

\footnotetext{
${ }^{1}$ A depth designation of $\mathbf{s}$ indicates that well or spring depth is less than 18.0 feet below land surface, a depth designation of $\mathbf{d}$ indicates that well depth is greater than or equal to 18.0 feet below land surface.

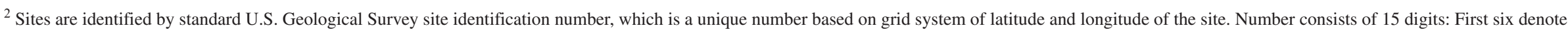

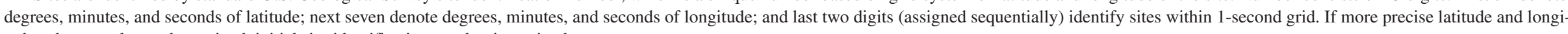
tude subsequently are determined, initial site-identification number is retained.

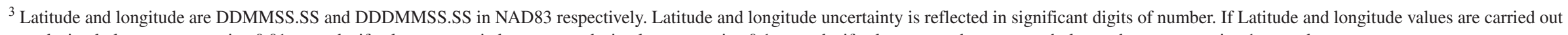
to two-decimal places, accuracy is \pm 0.01 seconds; if values are carried out to one-decimal, accuracy is \pm 0.1 seconds; if values are to the nearest whole number, accuracy is \pm 1 seconds.

${ }^{4}$ Water-quality data are available for this site.
} 
Table 2. Selected characteristics of surface-water site in Bijou Creek watershed, California, June-October 2003.

[Land-surface altitude was determined from precision Real-Time-Kinematic Global-Positioning-System survey.]

\begin{tabular}{|c|c|c|c|c|c|}
\hline $\begin{array}{c}\text { Site } \\
\text { no. } \\
\text { (fig. 1) }\end{array}$ & $\begin{array}{c}\text { USGS } \\
\text { site } \\
\text { identification } \\
\text { number }^{2}\end{array}$ & $\begin{array}{l}\text { Latitude } \\
\text { and } \\
\text { Iongitude }^{2}\end{array}$ & Station name & $\begin{array}{c}\text { Land- } \\
\text { surface } \\
\text { altitude } \\
\text { (feet } \\
\text { above } \\
\text { sea } \\
\text { level) }\end{array}$ & $\begin{array}{l}\text { Land- } \\
\text { surface } \\
\text { altitude } \\
\text { uncer- } \\
\text { tainty } \\
\text { (+ or } \\
\text { - feet) }\end{array}$ \\
\hline${ }^{3} 23$ & 385618119570101 & $\begin{array}{l}385618 \\
1195701\end{array}$ & $\begin{array}{l}\text { Bijou Creek tributary at Ski Run Blvd. } \\
\text { South Lake Tahoe, Ca. }\end{array}$ & 6,355 & 5 \\
\hline
\end{tabular}

\footnotetext{
${ }^{1}$ Sites are identified by standard U.S. Geological Survey site identification number, which is a unique number based on grid system of latitude and longitude of the site. Number consists of 15 digits: First six denote degrees, minutes, and seconds of latitude; next seven denote degrees, minutes, and seconds of longitude; and last two digits (assigned sequentially) identify sites within 1-second grid. If more precise latitude and longitude subsequently are determined, initial site-identification number is retained.

${ }^{2}$ Latitude and Longitude are DDMMSS.SS and DDDMMSS.SS in NAD83 respectively. Latitude and longitude uncertainty is \pm 1 seconds.

${ }^{3}$ Surface-water quality data is available for this site.
}

These results support the hypothesis that $\mathrm{NH}_{4}$ concentrations are greater in Bijou Creek watershed ground water than in the LTIMP ground-water network.

The median $\mathrm{NO}_{3}$ concentration was $0.229 \mathrm{mg} / \mathrm{L}$ in the Bijou Creek watershed ground water, which was nearly two times greater than the median $\mathrm{NO}_{3}$ concentration in the LTIMP ground-water network of $0.125 \mathrm{mg} / \mathrm{L}$ (table 3, fig. 4). The variability of $\mathrm{NO}_{3}$ concentration in the Bijou Creek watershed ground water was greater than in the LTIMP ground-water network. The IQR of $\mathrm{NO}_{3}$ concentrations measured in the Bijou Creek watershed ground water was $0.923 \mathrm{mg} / \mathrm{L}$, which was more than twice the IQR of the LTIMP ground-water network $(0.382 \mathrm{mg} / \mathrm{L})$. These results support the hypothesis that $\mathrm{NO}_{3}$ concentrations are greater in the Bijou Creek watershed ground water than in the LTIMP ground-water network. The maximum and median $\mathrm{NO}_{3}$ concentration in the deeper ground water of the Bijou Creek watershed was greater than in the shallow ground water (table 4). The minimum $\mathrm{NO}_{3}$ concentrations were identical.

The median DKN concentration was $0.15 \mathrm{mg} / \mathrm{L}$ in the Bijou Creek watershed ground water, which was 4 or more times greater than the median DKN concentration in the LTIMP ground-water network, which was $<0.04 \mathrm{mg} / \mathrm{L}$ (table 3, fig. 4). The variability of DKN concentration in the Bijou Creek watershed ground water also was greater than in the LTIMP ground-water network. The IQR of DKN concentration in the Bijou Creek watershed ground water was about $0.20 \mathrm{mg} / \mathrm{L}$, which was about 5 times greater than the IQR of the LTIMP ground-water network (IQR between $0.03 \mathrm{mg} / \mathrm{L}$ and $0.07 \mathrm{mg} / \mathrm{L}$ ). The maximum and median DKN concentra- tion in the shallow ground water of the Bijou Creek watershed was greater than in the deeper ground water (table 4). The minimum DKN concentration was near or below the method detection limit for both the shallow and deeper ground water. These results support the hypothesis that DKN concentrations are greater in the Bijou Creek watershed ground water than in the LTIMP ground-water network.

The median DOP concentration was $0.011 \mathrm{mg} / \mathrm{L}$ in the Bijou Creek watershed ground water, which was less than half the median concentration of DOP in the LTIMP ground-water network of $0.026 \mathrm{mg} / \mathrm{L}$ (table 3, fig. 4). The variability of DOP concentration in the Bijou Creek watershed ground water was less than in the LTIMP ground-water network. The IQR of DOP concentration in the Bijou Creek watershed ground water was $0.010 \mathrm{mg} / \mathrm{L}$, which was less than one third the IQR of the LTIMP ground-water network $(0.032 \mathrm{mg} / \mathrm{L})$. The maximum DOP concentration in the shallow ground water of the Bijou Creek watershed was almost 5 times greater than in the deep ground water (table 4). The median and minimum DOP concentrations in the shallow and deep ground water were similar. The hypothesis that DOP concentrations are greater in the Bijou Creek watershed ground water than in the LTIMP ground-water network is rejected.

The median DP concentration in the Bijou Creek watershed ground water was $0.028 \mathrm{mg} / \mathrm{L}$, which was less than the median concentration of $0.035 \mathrm{mg} / \mathrm{L}$ observed in the LTIMP ground-water network (table 3, fig. 4). The variability of DP concentration in the Bijou Creek watershed ground water was less than in the LTIMP ground-water network. The IQR of DP concentration in the Bijou Creek watershed ground water 

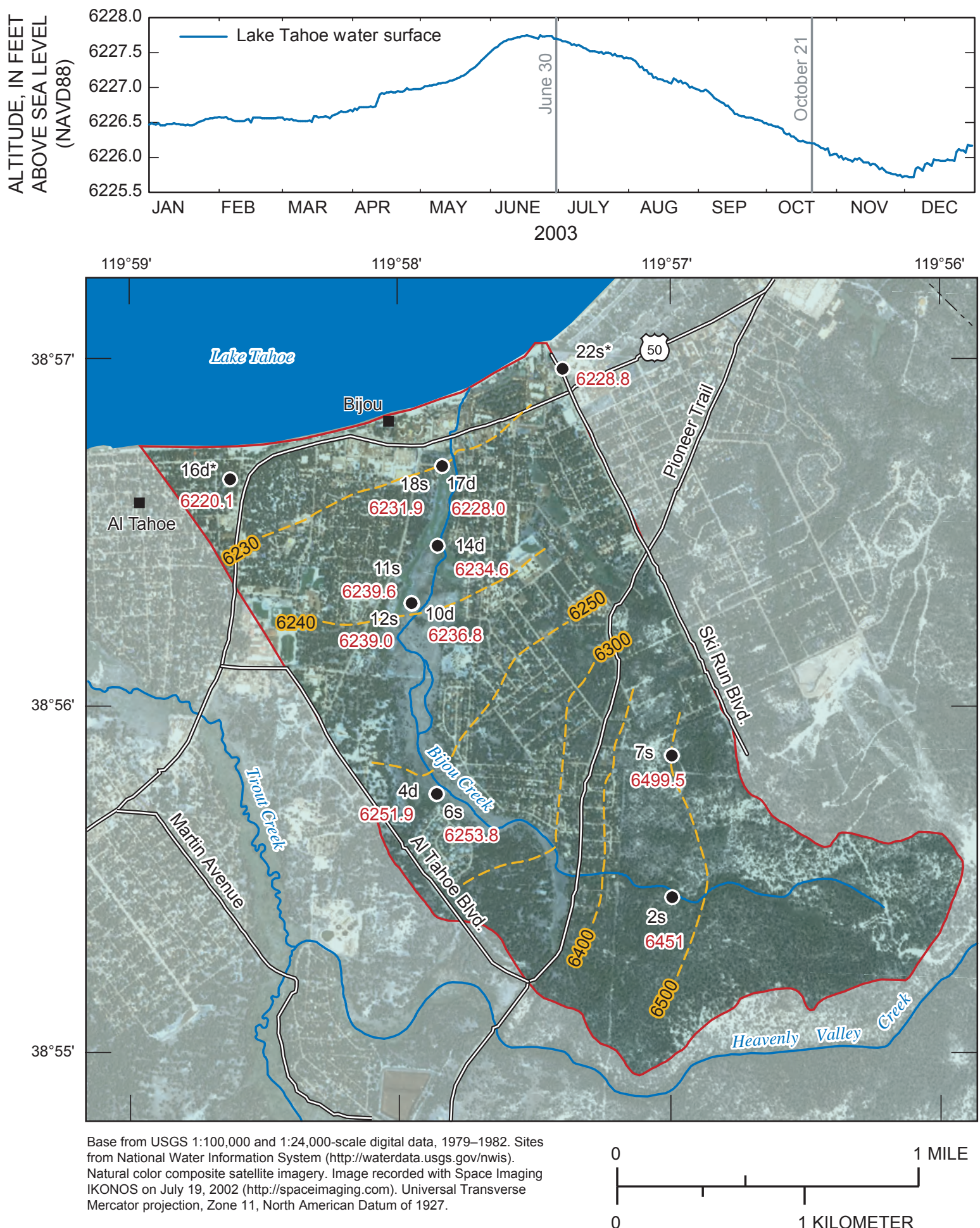

\section{EXPLANATION}

Approximate water-level contour-Indicates water-level in altitude above sea level.

Interval varies

\section{Study area boundary}

2s Ground-water sampling site-Upper number is 6451 site number followed by ground-water depth designation ( $\mathrm{s}$, less than 18 feet deep; d, greater than or equal to 18 feet deep). Asterisk indicates site measured in October 2003. Lower number is water-level altitude in feet above sea level

Figure 2. Map showing measured water levels in the Bijou Creek watershed (water levels measured between June 30 and August 6, 2003). 

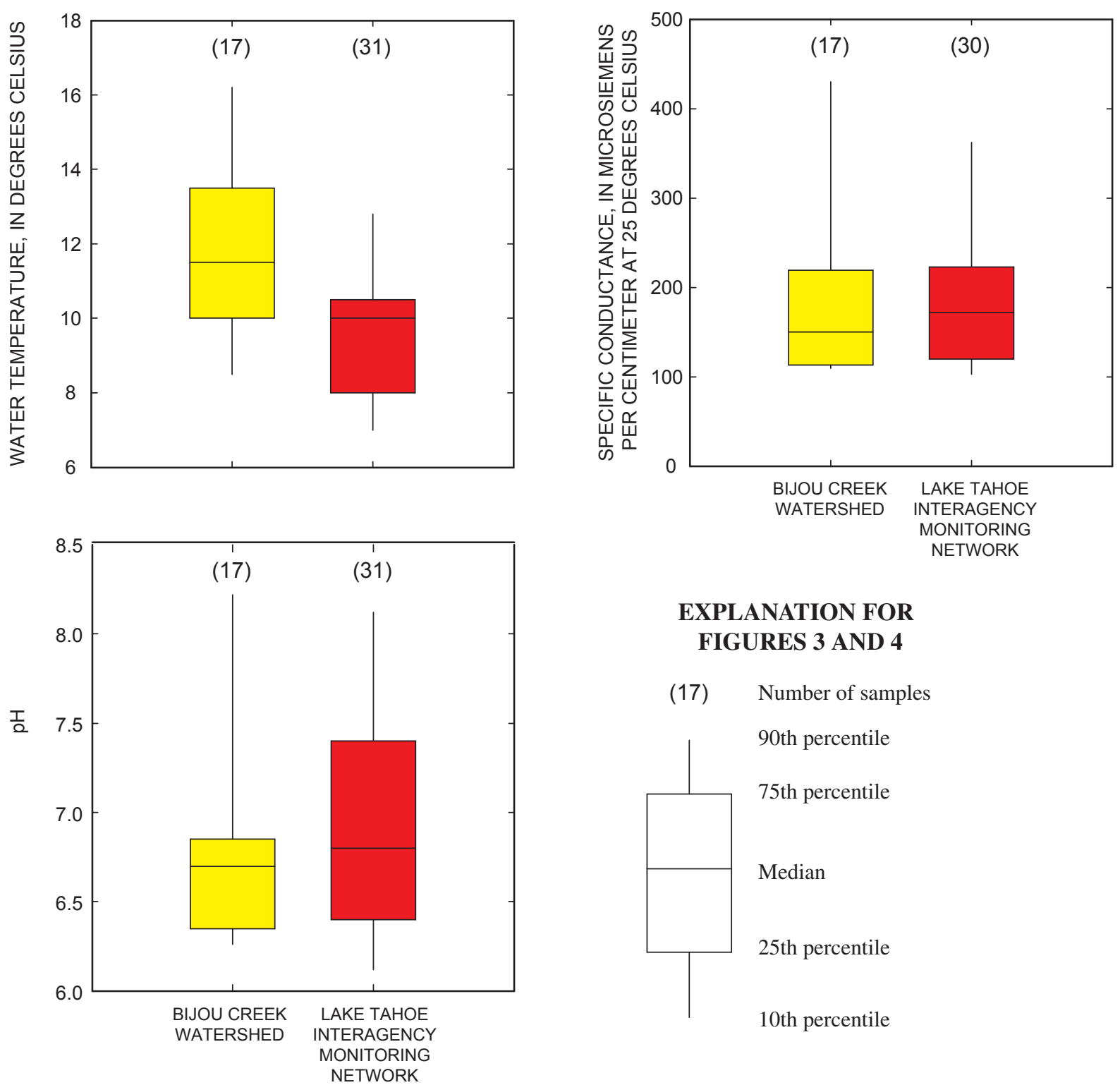

\section{EXPLANATION FOR FIGURES 3 AND 4}

(17) Number of samples

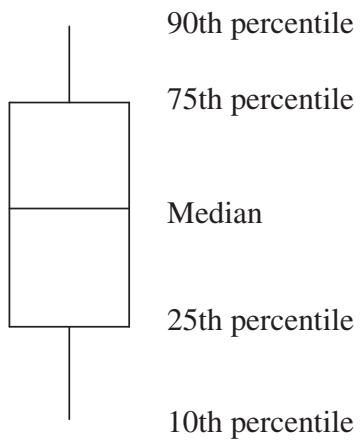

Figure 3. Boxplots showing distributions of water temperature, $\mathrm{pH}$, and specific conductance in samples from Bijou Creek watershed ground water during the summer of 2003 and in samples from the Lake Tahoe Interagency Monitoring Program ground-water network during the summer of 2002, Lake Tahoe, California and Nevada. 

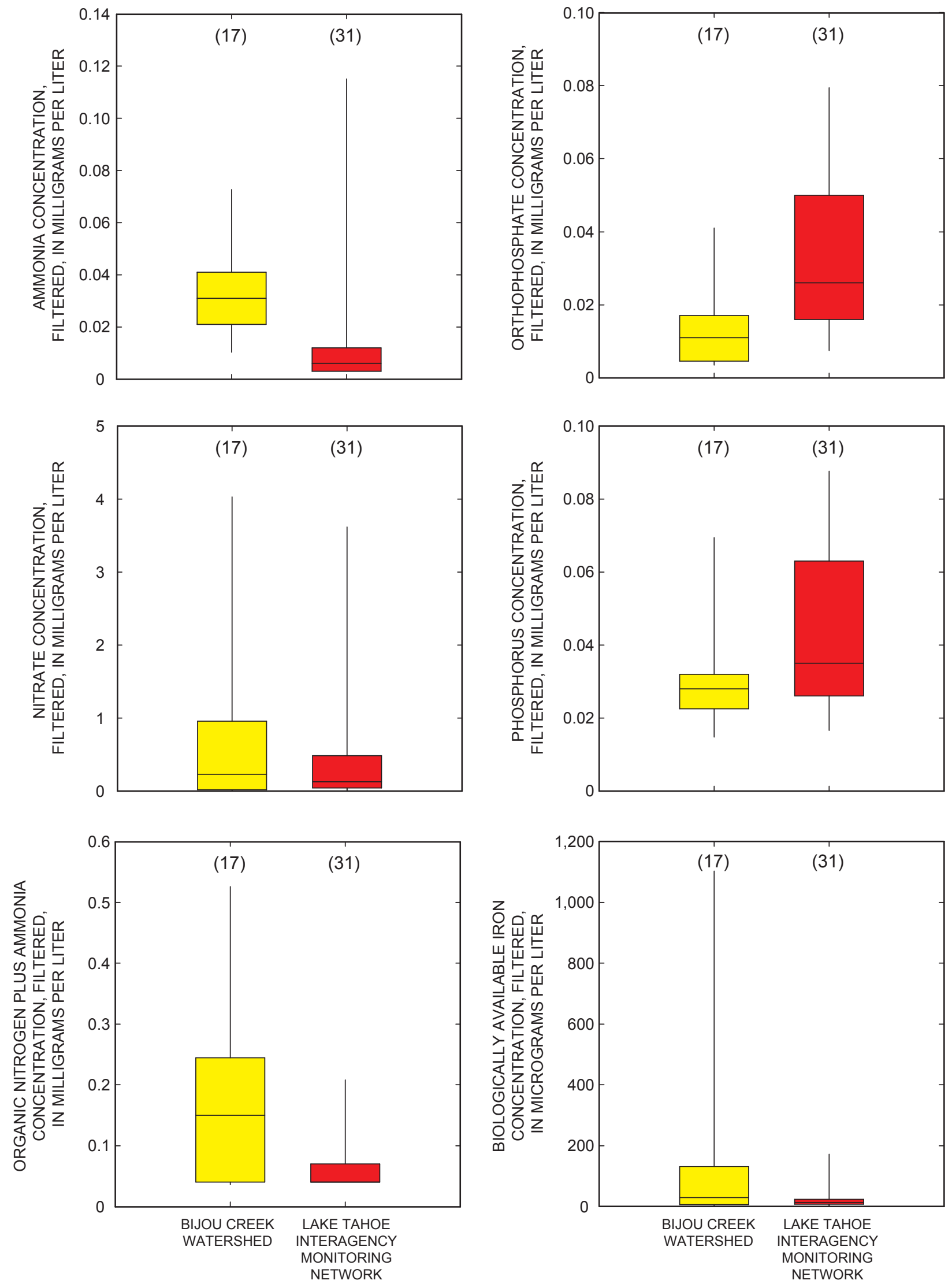

Figure 4. Boxplots showing distributions of filtered ammonia $\left(\mathrm{NH}_{4}\right)$, nitrate $\left(\mathrm{NO}_{3}\right)$, organic nitrogen plus ammonia (DKN), orthophosphate (DOP), phosphorus (DP), and biologically-available iron (DFe) concentrations in samples from Bijou Creek watershed ground water during the summer of 2003 and in samples from the Lake Tahoe Interagency Monitoring Program ground-water network during the summer of 2002 , Lake Tahoe, California and Nevada. 
Table 3. Statistical summary of water-quality data for ground-water sites sampled in Bijou Creek watershed, California, June-0ctober 2003 and for Lake Tahoe Interagency Monitoring Program ground-water network sampled during summer of 2002.

[Abbreviations: ${ }^{\circ} \mathrm{C}$, degrees Celsius; DFe, filtered biologically available iron; DKN, filtered ammonia plus organic nitrogen; DOP, filtered orthophosphate; DP, filtered phosphorus; $\mathrm{mg} / \mathrm{L}$, milligram per liter; $\mu \mathrm{g} / \mathrm{L}$; microgram per liter; $\mathrm{NH}_{4}$, filtered ammonia; $\mu \mathrm{S} / \mathrm{cm}$, microsiemens per centimeter; $\mathrm{NO}_{3}$, filtered nitrate; $\mathrm{SC}$, specific conductance; WT, water temperature; <, less than indicated value.]

\begin{tabular}{|c|c|c|c|c|c|c|c|c|c|}
\hline \multirow[b]{2}{*}{ Summary } & \multicolumn{3}{|c|}{ Field measurements } & \multicolumn{6}{|c|}{ Nutrients } \\
\hline & $\begin{array}{l}\text { WT } \\
\left({ }^{\circ} \mathrm{C}\right)\end{array}$ & $\begin{array}{c}\mathrm{pH} \\
\text { (standard } \\
\text { units) } \\
\end{array}$ & $\begin{array}{c}S C \\
(\mu \mathrm{S} / \mathrm{cm} \text { at } \\
\left.25^{\circ} \mathrm{C}\right) \\
\end{array}$ & $\begin{array}{c}\mathrm{NH}_{4} \\
\text { (mg/L as } \mathrm{N} \text { ) }\end{array}$ & $\begin{array}{c}\mathrm{NO}_{3} \\
\text { (mg/L as N) }\end{array}$ & $\begin{array}{c}\text { DKN } \\
\text { (mg/L as N) }\end{array}$ & $\begin{array}{c}\text { DOP } \\
(\mathrm{mg} / \mathrm{L} \text { as } \mathrm{P})\end{array}$ & $\begin{array}{c}\text { DP } \\
(\mathrm{mg} / \mathrm{L} \text { as } \mathrm{P})\end{array}$ & $\begin{array}{c}\text { DFe } \\
(\mu \mathrm{g} / \mathrm{L} \text { as Fe) }\end{array}$ \\
\hline \multicolumn{10}{|c|}{ Bijou Creek watershed study area ground-water sites } \\
\hline Sample Size & 17 & 17 & 17 & 17 & 17 & 17 & 17 & 17 & 17 \\
\hline Maximum & 17.0 & 8.3 & 490 & 0.120 & 4.34 & 0.55 & 0.093 & 0.103 & 3290 \\
\hline $90^{\text {th }}$ percentile & 16.0 & 7.4 & 305 & .053 & 2.37 & .41 & .023 & .048 & 390 \\
\hline $75^{\text {th }}$ percentile & 13.0 & 6.8 & 218 & .040 & 0.949 & .22 & .015 & .032 & 114 \\
\hline Median & 11.5 & 6.7 & 150 & .031 & .229 & .15 & .011 & .028 & 30 \\
\hline $25^{\text {th }}$ percentile & 10.0 & 6.4 & 114 & .022 & .026 & $<.04$ & .005 & .023 & 7 \\
\hline $10^{\text {th }}$ percentile & 8.8 & 6.3 & 111 & .016 & .014 & $<.04$ & .004 & .015 & 6 \\
\hline Minimum & 8.5 & 6.1 & 104 & .007 & .011 & $<.04$ & .001 & .014 & $<3$ \\
\hline \multicolumn{10}{|c|}{ LTIMP ground-water network } \\
\hline Sample Size & 31 & 31 & 30 & 31 & 31 & 31 & 31 & 31 & 31 \\
\hline Maximum & 15.5 & 8.4 & 467 & .640 & 7.82 & 2.0 & .277 & .282 & 7300 \\
\hline $90^{\text {th }}$ percentile & 12.0 & 7.8 & 316 & .020 & 1.41 & .20 & .073 & .086 & 100 \\
\hline $75^{\text {th }}$ percentile & 10.5 & 7.4 & 220 & .011 & .426 & .07 & .048 & .062 & 22 \\
\hline Median & 10.0 & 6.8 & 172 & .006 & .125 & $<.04$ & .026 & .035 & 13 \\
\hline $25^{\text {th }}$ percentile & 8.5 & 6.4 & 120 & $<.003$ & .043 & $<.04$ & .016 & .026 & 7 \\
\hline $10^{\text {th }}$ percentile & 7.0 & 6.2 & 106 & $<.003$ & .014 & $<.04$ & .009 & .019 & $<3$ \\
\hline Minimum & 5.5 & 5.6 & 81 & $<.003$ & .002 & $<.04$ & .002 & .011 & $<3$ \\
\hline
\end{tabular}


Table 4. Water-quality data and summary statistics on depth stratified water-quality data for ground-water sites sampled in Bijou Creek watershed, California, June-October 2003.

[Abbreviations: ${ }^{\circ} \mathrm{C}$, degrees Celsius; DFe, filtered biologically available iron; DKN, filtered ammonia plus organic nitrogen; DOP, filtered orthophosphate; DP, filtered phosphorus; E, estimated value; $\mathrm{mg} / \mathrm{L}$, milligram per liter; $\mu \mathrm{g} / \mathrm{L}$, microgram per liter; $\mu \mathrm{S} / \mathrm{cm}$, microsiemens per centimeter; $\mathrm{NH}_{4}$, filtered ammonia; $\mathrm{NO}_{3}$, filtered nitrate; SC, specific conductance; WT, water temperature;

$<$ less than indicated value.]

\begin{tabular}{|c|c|c|c|c|c|c|c|c|c|c|c|}
\hline \multirow{2}{*}{$\begin{array}{c}\text { Site no. } \\
\text { and depth desig- } \\
\text { nation' } \\
\text { (figure 1) }\end{array}$} & \multirow[b]{2}{*}{ Date } & \multirow[b]{2}{*}{ Time } & \multicolumn{3}{|c|}{ Field measurements } & \multicolumn{6}{|c|}{ Nutrients } \\
\hline & & & $\begin{array}{l}\text { WT } \\
\left({ }^{\circ} \mathrm{C}\right)\end{array}$ & $\begin{array}{c}\text { pH } \\
\text { (standard } \\
\text { units) }\end{array}$ & $\begin{array}{c}S C \\
(\mu S / c m \text { at } \\
\left.25^{\circ} \mathrm{C}\right) \\
\end{array}$ & $\begin{array}{c}\mathrm{NH}_{4} \\
\text { (mg/L as N) }\end{array}$ & $\begin{array}{c}\mathrm{NO}_{3} \\
\text { (mg/L as N) }\end{array}$ & $\begin{array}{c}\text { DKN } \\
\text { (mg/L as N) }\end{array}$ & $\begin{array}{c}\text { DOP } \\
(\mathrm{mg} / \mathrm{L} \text { as } \mathrm{P})\end{array}$ & $\begin{array}{c}\text { DP } \\
(\mathrm{mg} / \mathrm{L} \text { as } \mathrm{P})\end{array}$ & $\begin{array}{c}\text { DFe } \\
(\mu \mathrm{g} / \mathrm{L} \text { as Fe) }\end{array}$ \\
\hline $2 s$ & 09-29-2003 & 1440 & 10.5 & 6.4 & 111 & 0.011 & 0.017 & 0.06 & 0.019 & 0.023 & 47 \\
\hline $3 s$ & 09-24-2003 & 1330 & 13.0 & 6.9 & 150 & .040 & .042 & .21 & .093 & .103 & 3290 \\
\hline $4 \mathrm{~d}$ & 08-06-2003 & 1200 & 10.0 & 6.8 & 218 & .020 & .011 & .11 & .004 & .023 & 7 \\
\hline $6 s$ & 08-06-2003 & 1140 & 11.5 & 6.6 & 231 & .022 & .011 & .17 & .004 & .022 & 68 \\
\hline $8 \mathbf{d}$ & 08-06-2003 & 0805 & 14.0 & 6.7 & 114 & .031 & .965 & $<.04$ & .015 & .032 & 7 \\
\hline $9 \mathbf{d}$ & 08-05-2003 & 0820 & 8.5 & 6.7 & 112 & .031 & .949 & $<.04$ & .014 & .029 & 30 \\
\hline $10 \mathrm{~d}$ & 08-05-2003 & 0935 & 10.0 & 6.8 & 220 & .020 & 4.34 & .15 & .013 & .028 & 5 \\
\hline $11 \mathrm{~s}$ & 08-06-2003 & 0850 & 10.0 & 6.3 & 143 & .033 & 1.31 & .55 & .004 & .040 & 30 \\
\hline $13 \mathbf{d}$ & 08-13-2003 & 0710 & 11.0 & 8.2 & 111 & .033 & .043 & $<.04$ & .010 & .014 & 28 \\
\hline $14 \mathrm{~d}$ & 08-04-2003 & 1405 & 8.5 & 6.1 & 143 & .061 & .468 & .34 & .005 & .024 & 279 \\
\hline $15 d$ & 08-06-2003 & 1030 & 17.0 & 6.3 & 490 & .120 & 3.95 & .22 & .001 & .025 & 556 \\
\hline $17 \mathbf{d}$ & 08-06-2003 & 1005 & 12.0 & 6.5 & 180 & .029 & .125 & .18 & .009 & .028 & 6 \\
\hline $18 s$ & 08-06-2003 & 0950 & 16.0 & 6.3 & 171 & .048 & .016 & .52 & .028 & .061 & 114 \\
\hline $19 \mathbf{d}$ & $06-26-2002^{2}$ & 1500 & 12.0 & 6.6 & 189 & .007 & .565 & .06 & .020 & .032 & $<3$ \\
\hline $20 d$ & 08-13-2003 & 1015 & 12.0 & 8.3 & 133 & .028 & .229 & $<.04$ & .011 & .015 & 31 \\
\hline $21 \mathrm{~d}$ & 08-04-2003 & 1145 & 9.0 & 6.7 & 104 & .032 & .798 & $<.04$ & .013 & .028 & 6 \\
\hline $22 s$ & 08-13-2003 & 0930 & 16.0 & 6.9 & 415 & .042 & .026 & .27 & .009 & .015 & 147 \\
\hline \multicolumn{12}{|c|}{ Shallow/deep water-quality statistics } \\
\hline \multicolumn{3}{|c|}{ Maximum shallow/deep } & $16.0 / 17.0$ & $6.9 / 8.3$ & $415 / 490$ & $.048 / 0.120$ & $1.31 / 4.34$ & $.55 / .34$ & $.093 / .020$ & $.103 / .032$ & $3290 / 556$ \\
\hline \multicolumn{3}{|c|}{ Median shallow/deep } & $12.3 / 11.0$ & $6.5 / 6.7$ & $161 / 143$ & $.037 / .031$ & $.022 / .565$ & $.24 / .06$ & $.014 / .011$ & $.032 / .028$ & $91 / 7$ \\
\hline \multicolumn{3}{|c|}{ Minimum shallow/deep } & $10.0 / 8.5$ & $6.3 / 6.1$ & $111 / 104$ & $.011 / .007$ & $.011 / .011$ & $.06 / .04$ & $.004 / .001$ & $.015 / .014$ & $30 /<3$ \\
\hline
\end{tabular}

${ }^{1}$ A depth designation of $\mathbf{s}$ indicates that well or spring depth is less than 18.0 feet below land surface, a depth designation of $\mathbf{d}$ indicates that well depth is greater than or equal to 18.0 feet below land surface.

${ }^{2}$ Sample from June of 2002 was used for this site because this site was not sampled during the summer of 2003. 
was $0.009 \mathrm{mg} / \mathrm{L}$, which was nearly a quarter of the IQR of the LTIMP ground-water network $(0.035 \mathrm{mg} / \mathrm{L})$. The maximum DP concentration in the shallow ground water of the Bijou Creek watershed was over three times greater than in the deeper ground water (table 4). The median and minimum DP concentrations were similar. The hypothesis that DP concentrations are greater in the Bijou Creek watershed ground water than in the LTIMP ground-water network is rejected.

The median DFe concentration in the Bijou Creek watershed ground water was $30 \mu \mathrm{g} / \mathrm{L}$, which was more than twice the median concentration of $13 \mu \mathrm{g} / \mathrm{L}$ observed in the LTIMP ground-water network (table 3, fig. 4). The variability of DFe concentration in the Bijou Creek watershed ground water was greater than in the LTIMP ground-water network. The IQR of DFe concentration in the Bijou Creek watershed ground water was $107 \mu \mathrm{g} / \mathrm{L}$, which was about 7 times greater than the IQR of the LTIMP ground-water network $(15 \mu \mathrm{g} / \mathrm{L})$. The maximum, minimum, and median DFe concentrations in the shallow ground water of the Bijou Creek watershed were all greater than in the deeper ground water (table 4). These results support the hypothesis that DFe concentrations are greater in the Bijou Creek watershed ground water than in the LTIMP ground-water network.

\section{Time Series Data}

Water temperature and $\mathrm{pH}$ values appeared not to be changing with time at sites 19 and 21 (fig. 5). Specific conductance appeared to be changing with time for site 21 but not for site 19 (fig. 5). Specific-conductance data available for site 19 were not sufficient to conclude that there was a trend, but specific-conductance data at site 21 indicated a statistically significant increasing trend of about $1 \mu \mathrm{S} / \mathrm{cm} / \mathrm{yr}$ ( $\mathrm{p}$-value $<0.001$; table 5).

Concentrations of $\mathrm{NH}_{4}$ for sites 19 and 21 in the Bijou Creek watershed were at or below the method detection limit of $0.003 \mathrm{mg} / \mathrm{L}$ for all samples collected since December 1989 except for the last samples collected (fig. 6). Parametric trend test statistics were not computed for $\mathrm{NH}_{4}$ because of the large number of samples at or below the detection limit (table 5). The last sample collected for site 19 was on June 26, 2002, and the $\mathrm{NH}_{4}$ concentration was $0.007 \mathrm{mg} / \mathrm{L}$. The last sample collected at site 21 was on August 4, 2003, and the $\mathrm{NH}_{4}$ concentration was $0.032 \mathrm{mg} / \mathrm{L}$. Because the last $\mathrm{NH}_{4}$ concentration observed at site 21 was so much greater than all previous measurements, it is uncertain whether this sample was valid or was somehow contaminated. Laboratory quality control was in place and contamination did not appear to be a cause of this elevated concentration. More samples need to be collected from site 21 to determine if this anomalous concentration is due to changing $\mathrm{NH}_{4}$ concentration in the ground water or contamination.

Nitrate concentrations for sites 19 and 21 appear to be changing with time (fig. 6). However, even though $\mathrm{NO}_{3}$ concentration data at site 19 appears to have a statistically significant decreasing trend, this evaluation is artificial. The trend determination at site 19 is only significant because of seasonal variation of $\mathrm{NO}_{3}$ concentrations at this site and the influence of more frequently collected samples during the winter in the early part of the study period than during the later part. Nitrate concentration data at site 21 indicates a statistically significant increasing trend of about $0.040 \mathrm{mg} / \mathrm{L} / \mathrm{yr}$ (p-value <0.001; table 5). Concentrations of DKN for site 19 and 21 were mostly at or below the method detection limit of $0.04 \mathrm{mg} / \mathrm{L}$ (fig. 6) and did not appear to be changing with time. Parametric trend test statistics were not computed for DKN because of the large number of values at or below the method detection limit (table 5).

Filtered orthophosphate concentrations appear to be changing with time at site 21 , but not at site 19 (fig. 7). Filtered orthophosphate concentration data for site 19 did not indicate a statistically significant trend $(\mathrm{p}$-value $=0.417)$, but DOP concentration data for site 21 indicated a statistically significant (but very low) decreasing rate of about $0.001 \mathrm{mg} / \mathrm{L}$ every 4 years $(p$-value $=0.010$; table 5$)$. Filtered phosphorus concentration data for sites 19 and 21 did not indicate a statistically significant trend ( $\mathrm{p}$-value $=0.976$ and 0.687 , respectively; fig. 7, table 5). Biologically-available iron concentration data for sites 19 and 21 did not indicate statistically significant trend ( $\mathrm{p}$-value $=0.209$ and 0.862 , respectively; fig. 7, table 5).

\section{Spatial Distribution}

The spatial distribution of water temperature, $\mathrm{pH}$, and specific conductance in ground water of the Bijou Creek watershed displayed no obvious pattern. Water temperatures ranged from a minimum of $8.5^{\circ} \mathrm{C}$ at sites 9 and 14 to a maximum of $17.0^{\circ} \mathrm{C}$ at site 15 (tables 4 and 3 , fig. $8 \mathrm{~A}$ ). The surface-water site (site 23) had a water temperature of $12.5^{\circ} \mathrm{C}$, which was similar to the median ground-water temperature of $11.5^{\circ} \mathrm{C}$ (tables 6 and 3, fig. 8A). The $\mathrm{pH}$ of ground water in the Bijou Creek watershed was between 6.1 and 6.9, except for sites 13 and 20 in which the $\mathrm{pH}$ was 8.2 and 8.3 , respectively (table 4 , fig. 8B). The minimum pH of 6.1 occurred at site 14 (tables 4 and 3, fig. 8B). The surface-water site (site 23) had a near neutral $\mathrm{pH}$ of 7.3 (table 6, fig. 8B). Specific conductance ranged from a minimum of $104 \mu \mathrm{S} / \mathrm{cm}$ at site 21 to a maximum of $490 \mu \mathrm{S} / \mathrm{cm}$ at site 15 (tables 4 and 3, fig. 8C). The surface-water site (site 23) had a specific conductance of 531 $\mu \mathrm{S} / \mathrm{cm}$, which was greater than the maximum specific conductance observed in ground water in the study area (tables 6 and 3, fig. 8C).

The spatial distribution of $\mathrm{NH}_{4}, \mathrm{NO}_{3}$, and $\mathrm{DKN}$ in ground water of Bijou Creek watershed displayed no obvious pattern. Concentrations of $\mathrm{NH}_{4}$ ranged from a minimum of 0.007 $\mathrm{mg} / \mathrm{L}$ at site 19 , which is near the outlet of Bijou Creek to Lake Tahoe, to a maximum of $0.120 \mathrm{mg} / \mathrm{L}$ at site 15 (tables 4 and 3, fig. 9A). The single surface-water site (site 23) had an $\mathrm{NH}_{4}$ concentration of $0.105 \mathrm{mg} / \mathrm{L}$, which was greater than 

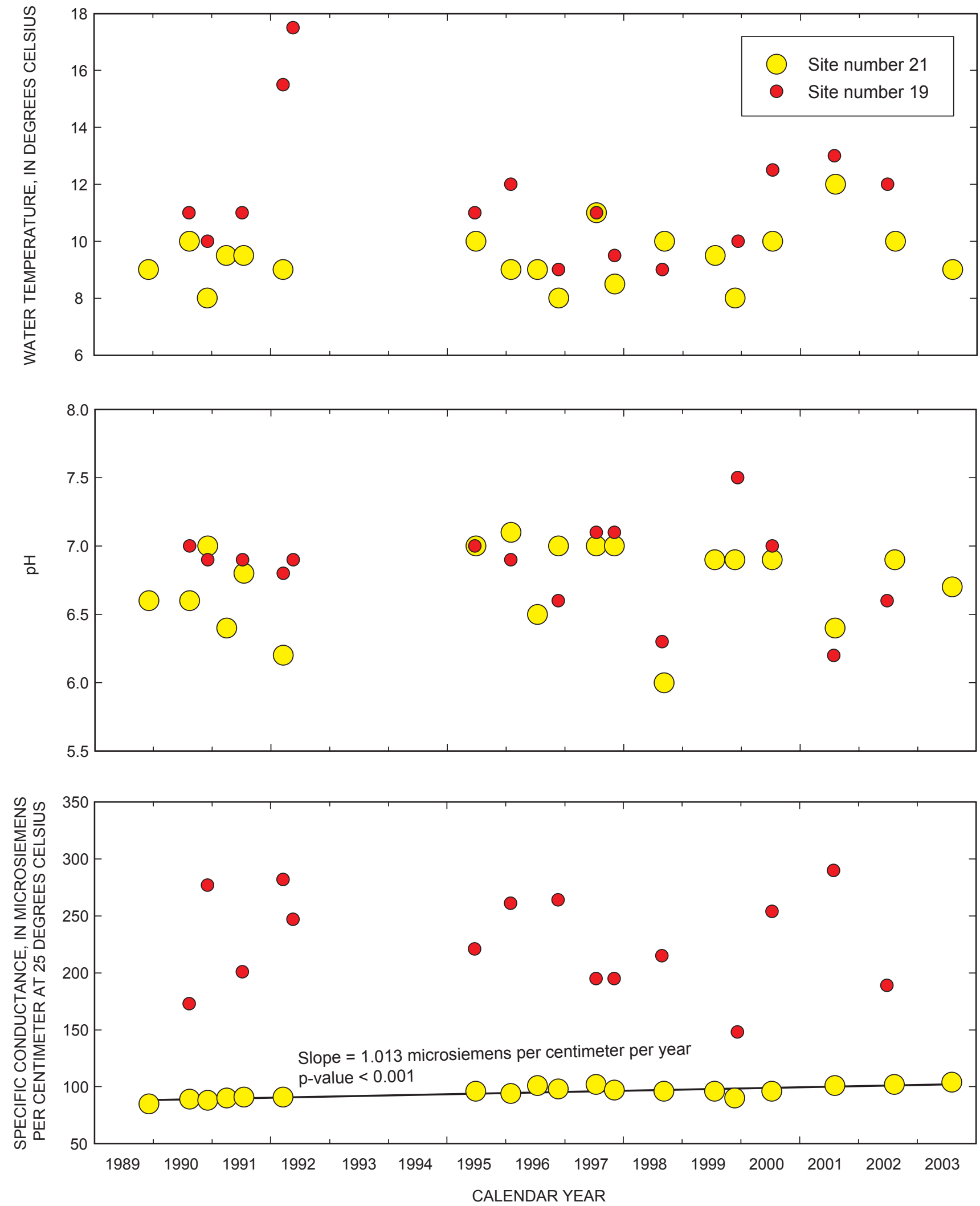

Figure 5. Time series plots of water temperature, $\mathrm{pH}$, and specific conductance. 
Table 5. Time series water-quality data and trend-test results for ground-water sites 19 and 21 in the Bijou Creek watershed, California.

[Abbreviations and symbols: E, estimated value; ${ }^{\circ} \mathrm{C}$, degrees Celsius; DFe, filtered biologically available iron; DKN, filtered ammonia plus organic nitrogen; DOP, filtered orthophosphate; $\mathrm{DP}$, filtered phosphorus; $\mu \mathrm{g} / \mathrm{L}$, microgram per liter; $\mu \mathrm{S} / \mathrm{cm}$, microsiemens per centimeter; $\mathrm{mg} / \mathrm{L}$, milligram per liter; $\mathrm{NH}_{4}$, filtered ammonia; $\mathrm{NO}_{3}$, filtered nitrate; $\mathrm{SC}$, specific conductance; units/yr, units per year; WT, water temperature; <, less than indicated value; --, not determined.]

\begin{tabular}{|c|c|c|c|c|c|c|c|c|c|c|}
\hline \multirow[b]{2}{*}{ Date } & \multirow[b]{2}{*}{ Time } & \multicolumn{3}{|c|}{ Field measurements } & \multicolumn{6}{|c|}{ Nutrients } \\
\hline & & $\begin{array}{l}\text { WT } \\
\left({ }^{\circ} \mathrm{C}\right)\end{array}$ & $\begin{array}{c}\mathrm{pH} \\
\text { (standard } \\
\text { units) }\end{array}$ & $\begin{array}{c}\mathrm{SC} \\
(\mu \mathrm{S} / \mathrm{cm} \text { at } \\
\left.25^{\circ} \mathrm{C}\right)\end{array}$ & $\begin{array}{c}\mathrm{NH}_{4} \\
\text { (mg/L as } \mathrm{N} \text { ) }\end{array}$ & $\begin{array}{c}\mathrm{NO}_{3} \\
\text { (mg/L as N) }\end{array}$ & $\begin{array}{c}\text { DKN } \\
\text { (mg/L as N) }\end{array}$ & $\begin{array}{c}\text { DOP } \\
\text { (mg/L as P) }\end{array}$ & $\begin{array}{c}\text { DP } \\
(\mathrm{mg} / \mathrm{L} \text { as } \mathrm{P})\end{array}$ & $\begin{array}{c}\text { DFe } \\
(\mu \mathrm{g} / \mathrm{L} \text { as } \mathrm{Fe})\end{array}$ \\
\hline \multicolumn{11}{|c|}{ Site no. 19} \\
\hline 08-13-1990 & 1215 & 11.0 & 7.0 & 173 & $<0.004$ & 0.635 & -- & 0.021 & 0.019 & -- \\
\hline $12-05-1990$ & 1500 & 10.0 & 6.9 & 277 & $<.004$ & 1.32 & 0.05 & .021 & .024 & 15 \\
\hline 07-09-1991 & 1600 & 11.0 & 6.9 & 201 & $<.004$ & .771 & .05 & .023 & .053 & 4 \\
\hline 05-19-1992 & 1200 & 17.5 & 6.9 & 247 & $<.004$ & .931 & $<.04$ & .022 & .032 & 5.8 \\
\hline 06-21-1995 & 1745 & 11.0 & 7.0 & 221 & $<.003$ & .710 & .09 & .021 & .061 & 13 \\
\hline 01-31-1996 & 1220 & 12.0 & 6.9 & 261 & $<.003$ & .739 & $<.04$ & .021 & .027 & 11 \\
\hline $11-21-1996$ & 1600 & 9.0 & 6.6 & 264 & $<.003$ & .705 & $<.04$ & .018 & .035 & 19 \\
\hline 07-15-1997 & 1430 & 11.0 & 7.1 & 195 & $<.003$ & .631 & .04 & .024 & .055 & 12 \\
\hline 11-04-1997 & 1600 & 9.5 & 7.1 & 195 & $<.003$ & .689 & .04 & .020 & .040 & 11 \\
\hline 08-27-1998 & 1430 & 9.0 & 6.3 & 215 & $<.003$ & .601 & .06 & .021 & .039 & 6.8 \\
\hline $07-12-2000$ & 1550 & 12.5 & 7.0 & 254 & $<.003$ & .746 & $<.04$ & .019 & .032 & 7.2 \\
\hline $07-30-2001$ & 1525 & 13.0 & 6.2 & 290 & $<.003$ & .877 & $<.04$ & .020 & .025 & 6.7 \\
\hline 06-26-2002 & 1500 & 12.0 & 6.6 & 189 & .007 & .565 & .06 & .020 & .032 & $<3$ \\
\hline \multicolumn{11}{|c|}{ Trend Statistics: } \\
\hline \multicolumn{2}{|c|}{$\overline{\text { Slope (units/yr) }}$} & -.123 & -.019 & -1.404 & -- & -.034 & -- & $-9.24 \times 10^{-5}$ & $2.65 \times 10^{-5}$ & -.466 \\
\hline \multicolumn{2}{|c|}{ Intercept (units) } & 257.46 & 44.40 & 3030.24 & -- & 67.86 & -- & .21 & -.02 & 940.38 \\
\hline \multicolumn{2}{|c|}{$\mathrm{p}$-value } & .454 & .406 & .648 & -- & $.030^{2}$ & -- & .417 & .976 & .209 \\
\hline \multicolumn{2}{|c|}{$\mathrm{R}^{2}$} & .04 & .05 & .02 & -- & .31 & -- & .05 & $<.01$ & .12 \\
\hline \multicolumn{2}{|c|}{ Trend $^{1}$} & No & No & No & -- & Decreasing $^{2}$ & -- & No & No & No \\
\hline
\end{tabular}


Table 5. Time series water-quality data and trend-test results for ground-water sites 19 and 21 in the Bijou Creek watershed, California--Continued

\begin{tabular}{|c|c|c|c|c|c|c|c|c|c|c|}
\hline \multirow[b]{2}{*}{ Date } & \multirow[b]{2}{*}{ Time } & \multicolumn{3}{|c|}{ Field measurements } & \multicolumn{6}{|c|}{ Nutrients } \\
\hline & & $\begin{array}{l}\text { WT } \\
\left({ }^{\circ} \mathrm{C}\right)\end{array}$ & $\begin{array}{c}\text { pH } \\
\text { (standard } \\
\text { units) }\end{array}$ & $\begin{array}{c}\text { SC } \\
(\mu \mathrm{S} / \mathrm{cm} \text { at } \\
\left.25^{\circ} \mathrm{C}\right)\end{array}$ & $\begin{array}{c}\mathrm{NH}_{4} \\
\text { (mg/L as } \mathrm{N} \text { ) }\end{array}$ & $\begin{array}{c}\mathrm{NO}_{3} \\
\text { (mg/L as N) }\end{array}$ & $\begin{array}{c}\text { DKN } \\
\text { (mg/L as N) }\end{array}$ & $\begin{array}{c}\text { DOP } \\
(\mathrm{mg} / \mathrm{L} \text { as } \mathrm{P})\end{array}$ & $\begin{array}{c}\text { DP } \\
(\mathrm{mg} / \mathrm{L} \text { as } \mathrm{P})\end{array}$ & $\begin{array}{c}\text { DFe } \\
(\mu \mathrm{g} / \mathrm{L} \text { as } \mathrm{Fe})\end{array}$ \\
\hline \multicolumn{11}{|c|}{ Site no. 21} \\
\hline $12-05-1989$ & 1050 & 9.0 & 6.6 & 85 & $<0.004$ & 0.271 & -- & 0.014 & 0.012 & -- \\
\hline $08-15-1990$ & 1430 & 10.0 & 6.6 & 89 & .004 & .211 & $<0.04$ & .016 & .069 & -- \\
\hline $12-05-1990$ & 1100 & 8.0 & 7.0 & 88 & $<.004$ & .245 & .05 & .013 & .015 & 4 \\
\hline 04-02-1991 & 930 & 9.5 & 6.4 & 90 & $<.004$ & .245 & $<.04$ & .015 & .022 & 4 \\
\hline 07-18-1991 & 1115 & 9.5 & 6.8 & 91 & $<.004$ & .251 & $<.04$ & .016 & .028 & 3 \\
\hline 03-18-1992 & 1215 & 9.0 & 6.2 & 91 & $<.004$ & .282 & $<.04$ & .017 & .020 & 19 \\
\hline 06-28-1995 & 1020 & 10.0 & 7.0 & 96 & $<.003$ & .465 & $<.04$ & .014 & .047 & 10 \\
\hline 02-01-1996 & 1310 & 9.0 & 7.1 & 94 & $<.003$ & .446 & $<.04$ & .015 & .016 & 7.9 \\
\hline 07-15-1996 & 950 & 9.0 & 6.5 & 101 & $<.003$ & .449 & $<.04$ & .014 & .055 & 8.5 \\
\hline $11-22-1996$ & 1240 & 8.0 & 7.0 & 98 & $<.003$ & .430 & $<.04$ & .014 & .020 & 29 \\
\hline 07-15-1997 & 1345 & 11.0 & 7.0 & 102 & $<.003$ & .540 & $<.04$ & .017 & .054 & 13 \\
\hline $11-05-1997$ & 1510 & 8.5 & 7.0 & 97 & $<.003$ & .449 & $<.04$ & .013 & .032 & 7.3 \\
\hline 09-10-1998 & 1455 & 10.0 & 6.0 & 96 & $<.003$ & .485 & .09 & .013 & .020 & 7.5 \\
\hline 07-21-1999 & 1115 & 9.5 & 6.9 & 96 & $<.003$ & .478 & .05 & .010 & .026 & 4.7 \\
\hline 11-23-1999 & 1400 & 8.0 & 6.9 & 90 & $<.003$ & .431 & $<.04$ & .012 & .022 & 5 \\
\hline $07-12-2000$ & 1505 & 10.0 & 6.9 & 96 & $<.003$ & .460 & $<.04$ & .012 & .023 & 7.9 \\
\hline 08-07-2001 & 1225 & 12.0 & 6.4 & 101 & $<.003$ & .481 & .07 & .013 & .018 & 5.2 \\
\hline 08-13-2002 & 1445 & 10.0 & 6.9 & 102 & $<.003$ & 1.14 & .04 & .013 & .024 & 17 \\
\hline 08-04-2003 & 1145 & 9.0 & 6.7 & 104 & .032 & .798 & $<.04$ & .013 & .028 & 6 \\
\hline \multicolumn{11}{|c|}{ Trend Statistics: } \\
\hline \multicolumn{2}{|c|}{$\overline{\text { Slope (units/yr) }}$} & .060 & .010 & 1.013 & -- & .040 & -- & $-2.372 \times 10^{-4}$ & $-3.57 \times 10^{-4}$ & 0.078 \\
\hline \multicolumn{2}{|c|}{ Intercept (units) } & -110.81 & -13.36 & -1927.40 & -- & -79.39 & -- & .487 & .742 & -145.95 \\
\hline \multicolumn{2}{|c|}{ p-value } & .288 & .566 & $<.001$ & -- & $<.001$ & -- & .010 & .687 & .862 \\
\hline \multicolumn{2}{|c|}{$\mathrm{R}^{2}$} & .07 & .02 & .65 & -- & .64 & -- & .33 & .01 & $<.01$ \\
\hline \multicolumn{2}{|c|}{ Trend $^{1}$} & No & No & Increasing & -- & Increasing & -- & Decreasing & No & No \\
\hline
\end{tabular}

${ }^{1}$ Trend was significant when p-value was less than a pre-determined $\alpha$-value of 0.05 . [No, data available is not sufficient to reject the null hypothesis that there is no trend; Increasing or Decreasing, null hypothesis is rejected in favor of the alternate hypothesis that there is a trend in the direction of the slope.]

${ }^{2}$ This trend determination is only significant because of seasonal effect on $\mathrm{NO}_{3}$ concentrations and the fact that there were more winter samples included at the beginning of the period than at the end. If winter samples are removed from the data set, then there is no significance to the trend. 

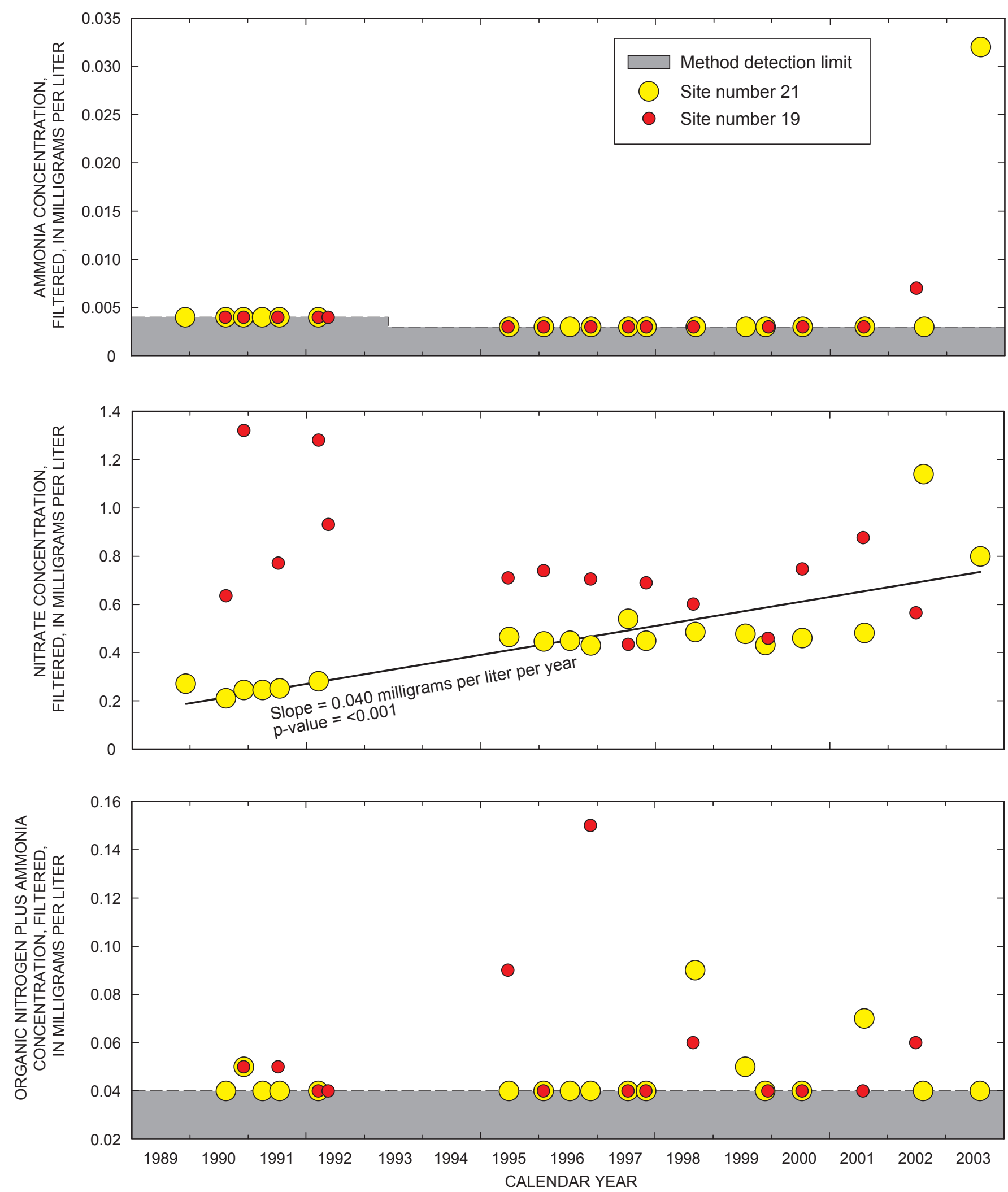

Figure 6. Time series plots of filtered ammonia $\left(\mathrm{NH}_{4}\right)$, nitrate $\left(\mathrm{NO}_{3}\right)$, and organic nitrogen plus ammonia (DKN) concentrations. 

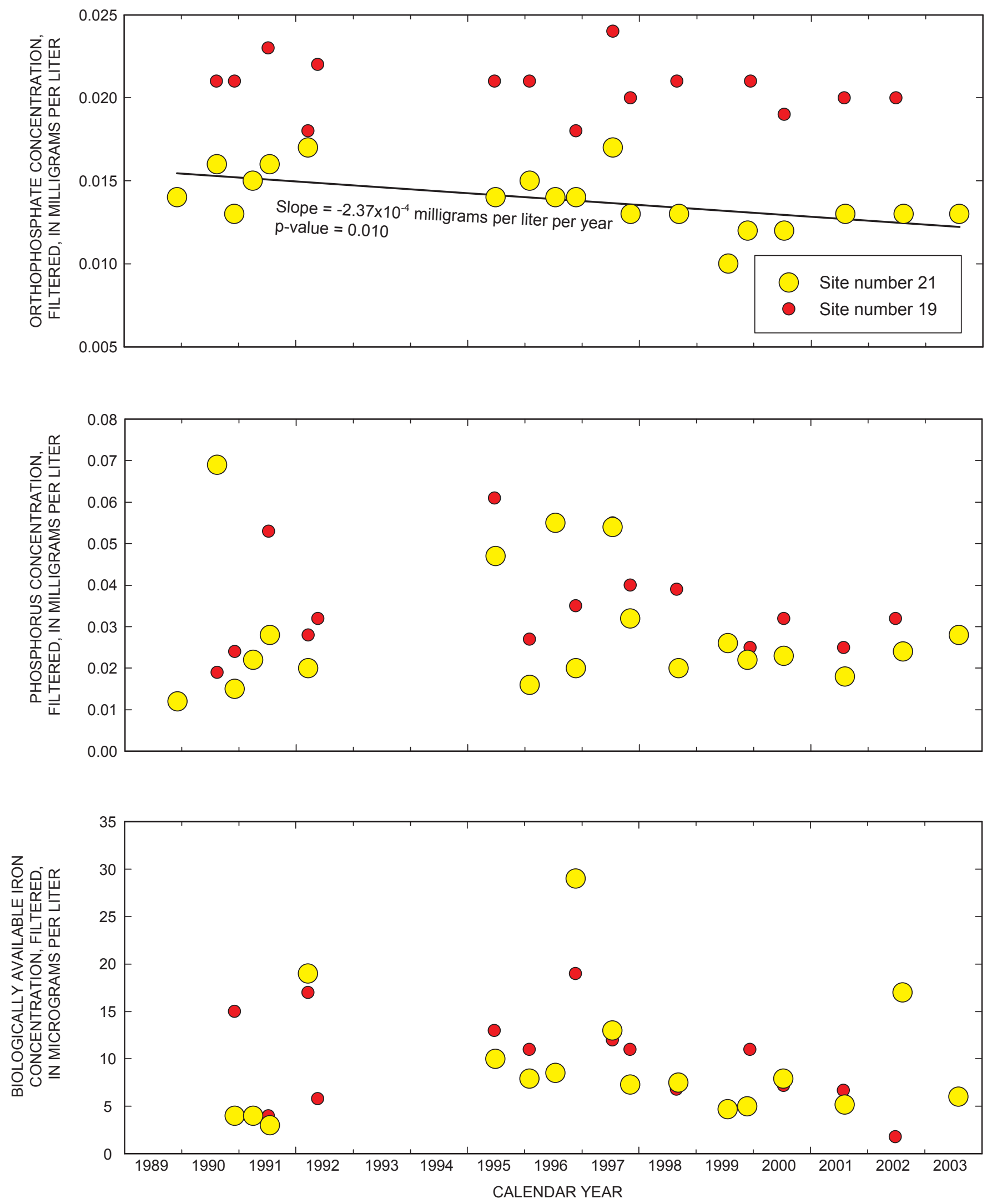

Figure 7. Time series plots of orthophosphate (DOP), phosphorus (DP), and biologically-available iron (DFe) concentrations. 
$\boldsymbol{A}$

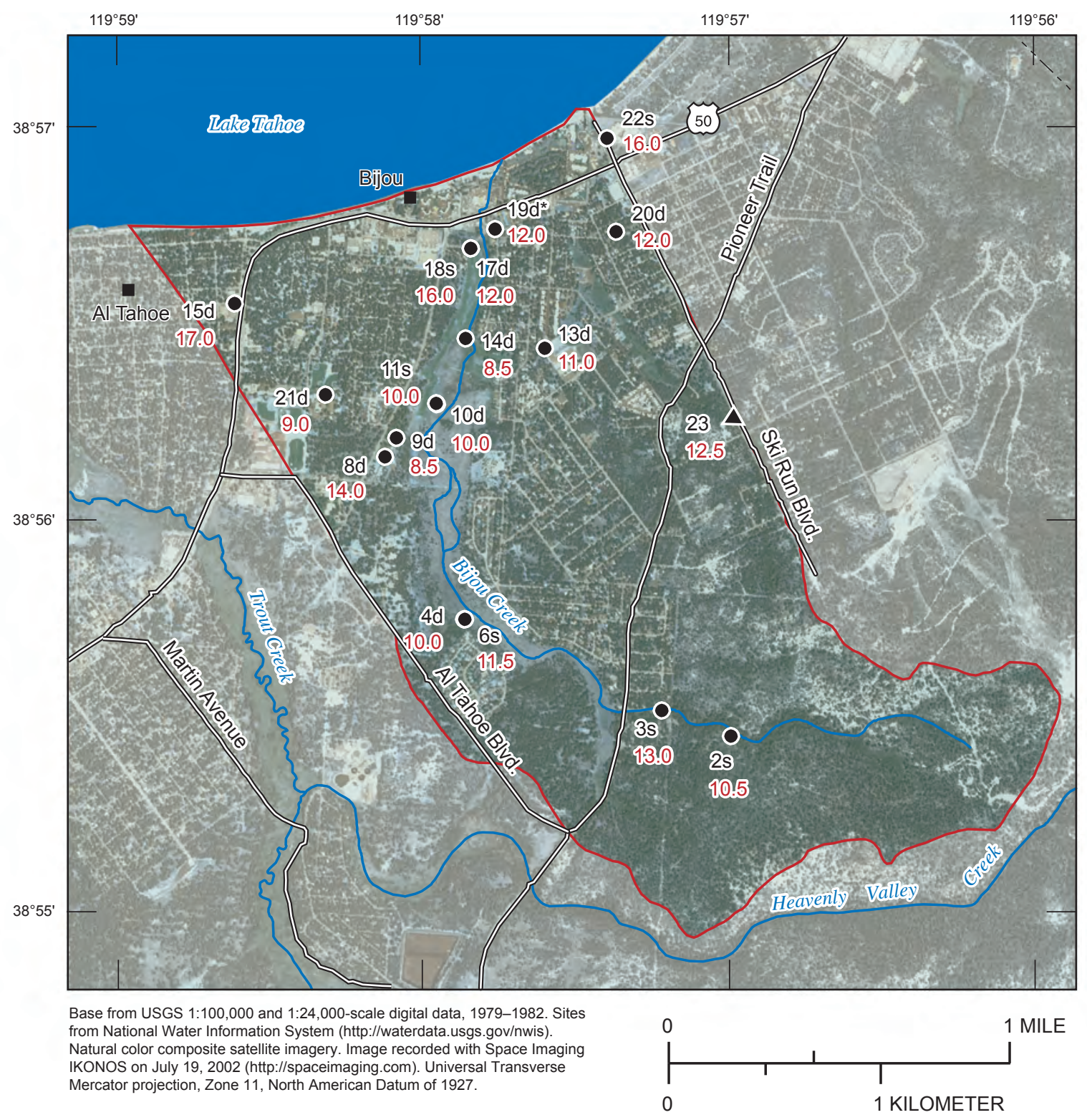

\section{EXPLANATION}

Study area boundary

Sampling site location-Lower number is water temperature, in degrees Celsius

21 Ground-water site-Upper number is site number followed by ground-water depth designation (s, less than 18 feet deep; d, greater than or equal to 18 feet deep). Asterisk indicates site sampled in June 2002

23 Surface-water site-Upper number is site number

Figure 8. Maps showing field measured values in the Bijou Creek watershed, California, for $(\boldsymbol{A})$ water temperature, (B) $\mathrm{pH}$, and (C) specific conductance. 


\section{B}

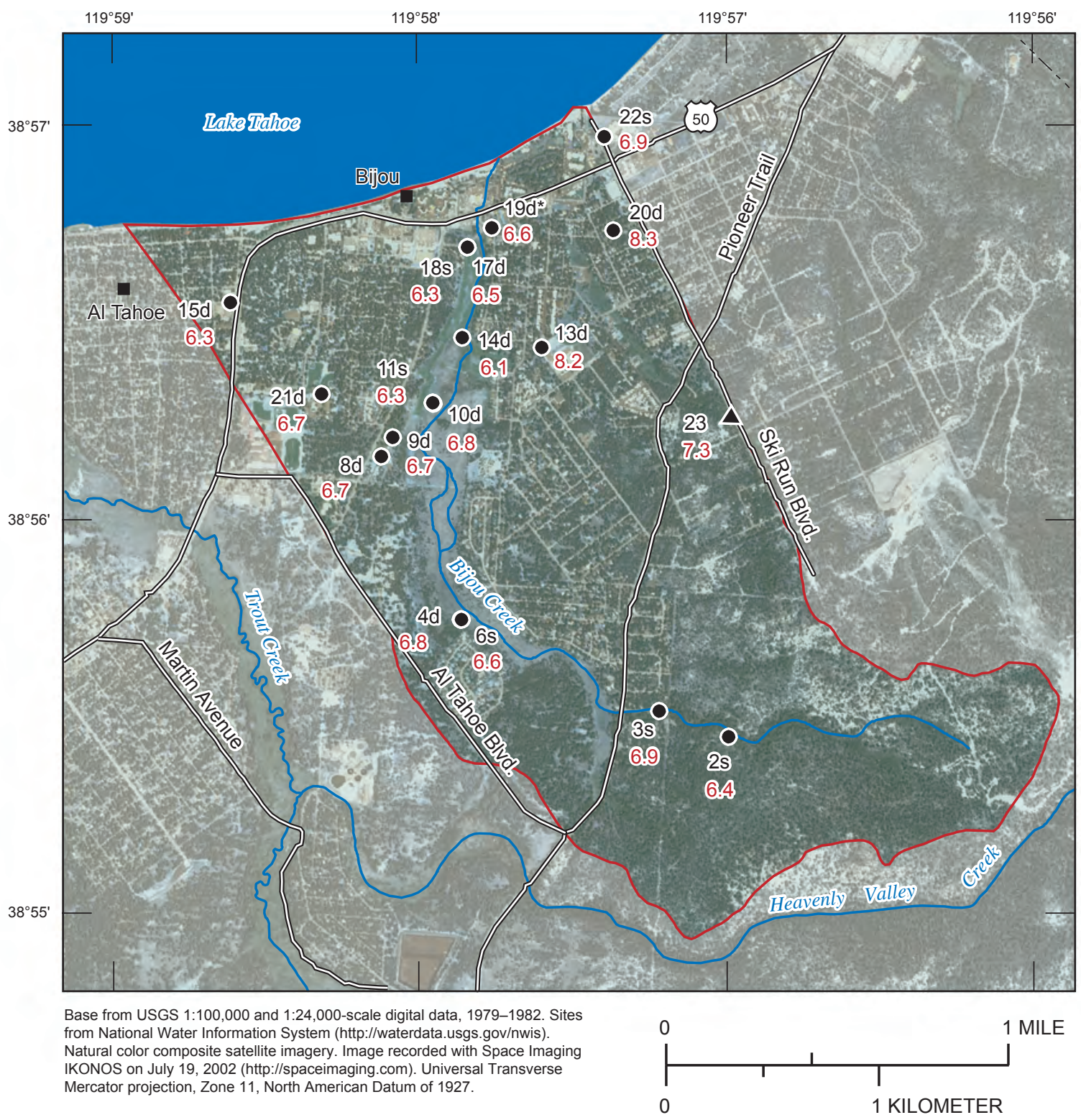

\section{EXPLANATION}

\section{Study area boundary}

Sampling site location-Lower number is $\mathrm{pH}$

21 Ground-water site-Upper number is site number followed by ground-water depth designation (s, less than 18 feet deep; d, greater than or equal to 18 feet deep). Asterisk indicates site sampled in June 2002

23 Surface-water site-Upper number is site number

Figure 8B. pH 


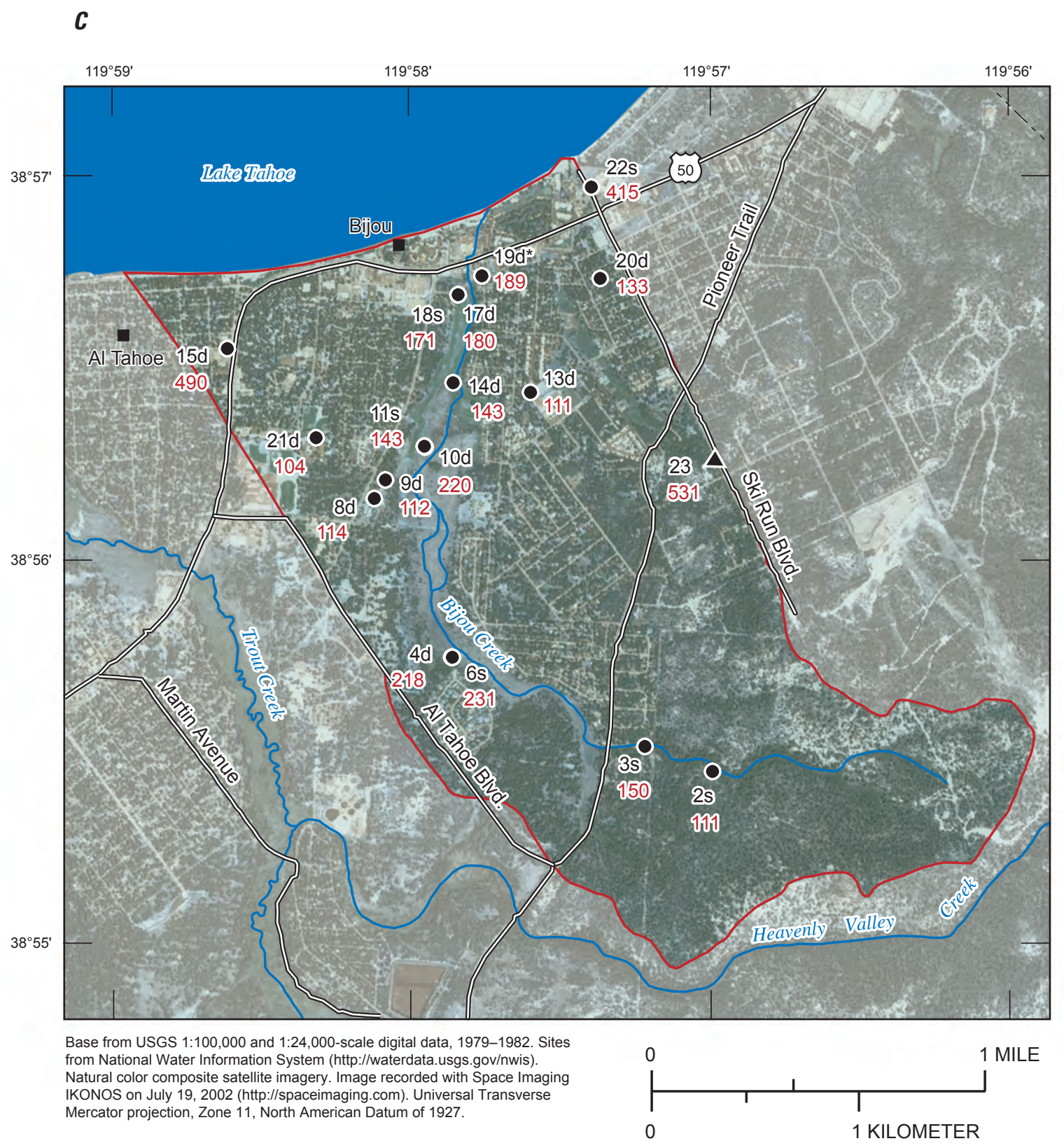

\section{EXPLANATION}

Study area boundary

Sampling site location-Lower number is specific conductance, in microsiemens per centimeter at 25 degrees Celsius

21 - Ground-water site-Upper number is site number followed by ground-water depth designation (s, less than 18 feet deep; d, greater than or equal to 18 feet deep). Asterisk indicates site sampled in June 2002

23 Surface-water site-Upper number is site number

Figure 8 C. Specific conductance 
the majority of $\mathrm{NH}_{4}$ concentrations for the ground-water sites (tables 6 and 3, fig. 9A). Concentration of $\mathrm{NO}_{3}$ ranged from a minimum of $0.011 \mathrm{mg} / \mathrm{L}$ at sites 4 and 6 (wells are collocated but are screened at different depths), to a maximum of 4.34 $\mathrm{mg} / \mathrm{L}$ at site 10, which is in the Bijou Community Golf Course (tables 4 and 3, fig. 9B). The surface-water site (site 23) had a $\mathrm{NO}_{3}$ concentration of $0.051 \mathrm{mg} / \mathrm{L}$, which is less than the median $\mathrm{NO}_{3}$ concentration found in the Bijou Creek watershed ground water $(0.229 \mathrm{mg} / \mathrm{L}$; tables 6 and 3, fig. 9B). DKN concentrations ranged from a minimum below the method detection level of $0.04 \mathrm{mg} / \mathrm{L}$ at five sites (sites 8, 9, 13, 20, and 21), to a maximum of $0.55 \mathrm{mg} / \mathrm{L}$ at site 11 (tables 4 and 3, fig. 9C). The surface-water site (site 23) had a DKN concentration of $0.33 \mathrm{mg} / \mathrm{L}$, which is greater than twice the median DKN concentration in the ground water of Bijou Creek watershed $(0.15 \mathrm{mg} / \mathrm{L}$; tables 6 and 3, fig. $9 \mathrm{C})$. The TKN concentration at site 23 consisted almost entirely of the dissolved fraction with only three percent of the TKN being associated with particulate KN (table 6).

The concentration of DOP was the greatest on the east side of the study area at site $3(0.093 \mathrm{mg} / \mathrm{L})$, and the least on the west side of the study area at site $15(0.001 \mathrm{mg} / \mathrm{L}$; tables 4 and 3, fig. 9D). The remainder of the ground-water DOP concentrations observed were between 0.004 and $0.028 \mathrm{mg} / \mathrm{L}$ (table 4, fig. 9D). The surface-water site (site 23) had a DOP concentration of $0.036 \mathrm{mg} / \mathrm{L}$, which is greater than the 90 th percentile concentration of ground water in the study area (tables 6 and 3, fig. 9D).

The spatial distribution of DP and DFe concentrations in ground water of Bijou Creek watershed displayed no obvious pattern. Concentrations of DP ranged from a minimum of $0.014 \mathrm{mg} / \mathrm{L}$ at site 13 to a maximum of $0.103 \mathrm{mg} / \mathrm{L}$ at site 3 (tables 4 and 3, fig. 9E). The surface-water site (site 23) had a DP concentration of $0.043 \mathrm{mg} / \mathrm{L}$, which is greater than the 75th percentile of DP in ground water (tables 6 and 3, fig. 9E). The majority of the DP observed at site 23 was associated with DOP (approximately 84 percent; table 6). Total phosphorus was not analyzed so it is unknown how much phosphorus was associated with the particulate fraction. DFe concentrations ranged from a minimum of less than the $3 \mu \mathrm{g} / \mathrm{L}$ method detection level at site 19 , to a maximum of $3,290 \mu \mathrm{g} / \mathrm{L}$ at site 3 (tables 4 and 3, fig. 9F). The surface-water site (site 23) had a DFe concentration of $2,100 \mu \mathrm{g} / \mathrm{L}$, which is greater than the 90th percentile concentration in ground water in the study area (tables 6 and 3, fig. 9F). DFe accounted for approximately half (48 percent) of the total iron measured at the surface-water site with the other half ( 52 percent) being the particulate fraction (table 6).

The surface of the water table generally paralleled the pattern of land topography (fig. 2). Water-level altitude was greatest at the site with the highest land-surface altitude $(6,499.5 \mathrm{ft}$ at site 7$)$ and was the lowest at site 16 near the lakeshore (6,220.1 ft; table 1, fig. 2). Water-level altitudes generally decreased from south to north, towards Lake Tahoe (fig. 2). For the sites with multiple adjacent wells (sites 4, 5, and 6 ; sites 10, 11, and 12; sites 17 and 18), the water-level altitude was always greater in the shallow well than in the deeper well indicating a downward gradient (table 1, fig. 2). The altitude of the surface of Lake Tahoe during the study period ranged from a maximum of $6,227.7 \mathrm{ft}$ on June 30, 2003 and steadily declined to a low of $6,226.2 \mathrm{ft}$ on October 21 , 2003 (see graph on fig. 2; Stockton and others, 2003; Bonner and others, 2004).

Ground-water altitudes were higher than the surface of Lake Tahoe at all sites except for well 16 (table 1, fig. 2). Water levels at well 16 probably are affected by pumping of two nearby production wells in the Al Tahoe community. The water levels indicate that ground water is discharging into Lake Tahoe along the majority of the Bijou Creek study area shoreline. This suggests that elevated nutrient concentrations in ground water from the Bijou Creek Watershed may be contributing to the elevated turbidity observed in the nearshore environment.

\section{Summary}

A reconnaissance study of ground water was done in the Bijou Creek watershed during the summer of 2003. Existing wells, springs, and a surface-water site were located, water levels were measured, water samples were collected for nutrient analysis, and water temperature, $\mathrm{pH}$, and specific conductance were measured. Data were collected from a total of 23 sites with nutrient samples being collected from 18 sites and water levels were measured at 13 sites.

Water temperature in the Bijou Creek watershed ground water was slightly greater than in the LTIMP ground-water network, but variability was similar. Specific conductance and $\mathrm{pH}$ were similar between the Bijou Creek watershed ground water and the LTIMP ground-water network, and variability was similar for specific conductance, but less for $\mathrm{pH}$. Water temperature, $\mathrm{pH}$, and specific conductance in the shallow and deep ground water of the Bijou Creek watershed did not appear to differ.

Nitrogen concentrations in ground water from the Bijou Creek watershed were greater than in LTIMP ground-water network for $\mathrm{NH}_{4}, \mathrm{NO}_{3}$, and DKN. The variability in measured concentration for all three nitrogen species $\left(\mathrm{NH}_{4}, \mathrm{NO}_{3}\right.$, and DKN) was greater in the Bijou Creek watershed than in the LTIMP ground-water network. $\mathrm{NH}_{4}$ concentrations in the shallow and deep ground water of the Bijou Creek watershed did not appear to be different. $\mathrm{NO}_{3}$ concentrations, however, appeared to be greater in the deeper ground water than in the shallow ground water and DKN concentrations appeared to be greater in the shallow ground water than in the deeper ground water.

Phosphorus concentrations in the Bijou Creek watershed ground water were less than in the LTIMP ground-water network for DP and DOP. The variability in measured phosphorus concentrations were also less in the Bijou Creek watershed than in the LTIMP ground-water network. Concentration and 
Table 6. Water-quality data for surface-water site sampled in Bijou Creek watershed, California, during summer of 2003.

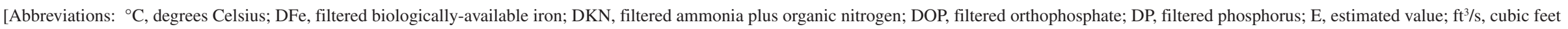
per second; $\mu \mathrm{g} / \mathrm{L}$, microgram per liter; $\mathrm{mg} / \mathrm{L}$, milligram per liter; $\mu \mathrm{S} / \mathrm{cm}$, microsiemens per centimeter; $\mathrm{NH}_{4}$, filtered ammonia; $\mathrm{NO}_{3}$, filtered nitrate; $\mathrm{Q}$, streamflow; $\mathrm{SC}$, specific conductance; TFe, unfiltered biologically-available iron; TKN, unfiltered ammonia plus organic nitrogen; WT, water temperature.

\begin{tabular}{|c|c|c|c|c|c|c|c|c|c|c|c|c|c|c|}
\hline \multirow[b]{2}{*}{$\begin{array}{c}\text { Site no. } \\
\text { (fig 1) }\end{array}$} & \multirow[b]{2}{*}{ Date } & \multirow[b]{2}{*}{ Time } & \multicolumn{4}{|c|}{ Field measurements } & \multicolumn{8}{|c|}{ Nutrients } \\
\hline & & & $\begin{array}{l}\text { WT } \\
\left({ }^{\circ} \mathrm{C}\right)\end{array}$ & $\begin{array}{c}0 \\
\left(\mathrm{ft}^{3} / \mathrm{s}\right)\end{array}$ & $\begin{array}{c}\mathrm{pH} \\
\text { (standard } \\
\text { units) }\end{array}$ & $\begin{array}{c}\mathrm{SC} \\
(\mu \mathrm{S} / \mathrm{cm} \text { at } \\
\left.25^{\circ} \mathrm{C}\right) \\
\end{array}$ & $\begin{array}{c}\mathrm{NH}_{4} \\
(\mathrm{mg} / \mathrm{L} \text { as } \\
\mathrm{N})\end{array}$ & $\begin{array}{c}\mathrm{NO}_{3} \\
(\mathrm{mg} / \mathrm{L} \text { as } \\
\mathrm{N})\end{array}$ & $\begin{array}{c}\text { DKN } \\
\text { (mg/L as } \\
\mathrm{N})\end{array}$ & $\begin{array}{c}\text { TKN } \\
\text { (mg/L as } \\
\mathrm{N})\end{array}$ & $\begin{array}{c}\text { DOP } \\
\text { (mg/L as } \\
\text { P) }\end{array}$ & $\begin{array}{c}\text { DP } \\
\text { (mg/L as } \\
\text { P) }\end{array}$ & $\begin{array}{c}\text { DFe } \\
\text { ( } \mu \mathrm{g} / \mathrm{L} \text { as } \\
\mathrm{Fe}) \\
\end{array}$ & $\begin{array}{c}\text { TFe } \\
\text { ( } \mu \mathrm{g} / \mathrm{L} \text { as } \\
\mathrm{Fe}) \\
\end{array}$ \\
\hline 23 & $09-23-2003$ & 1445 & 12.5 & E0.1 & 7.3 & 531 & 0.105 & 0.051 & 0.33 & 0.34 & 0.036 & 0.043 & 2100 & 4340 \\
\hline
\end{tabular}


$\boldsymbol{A}$

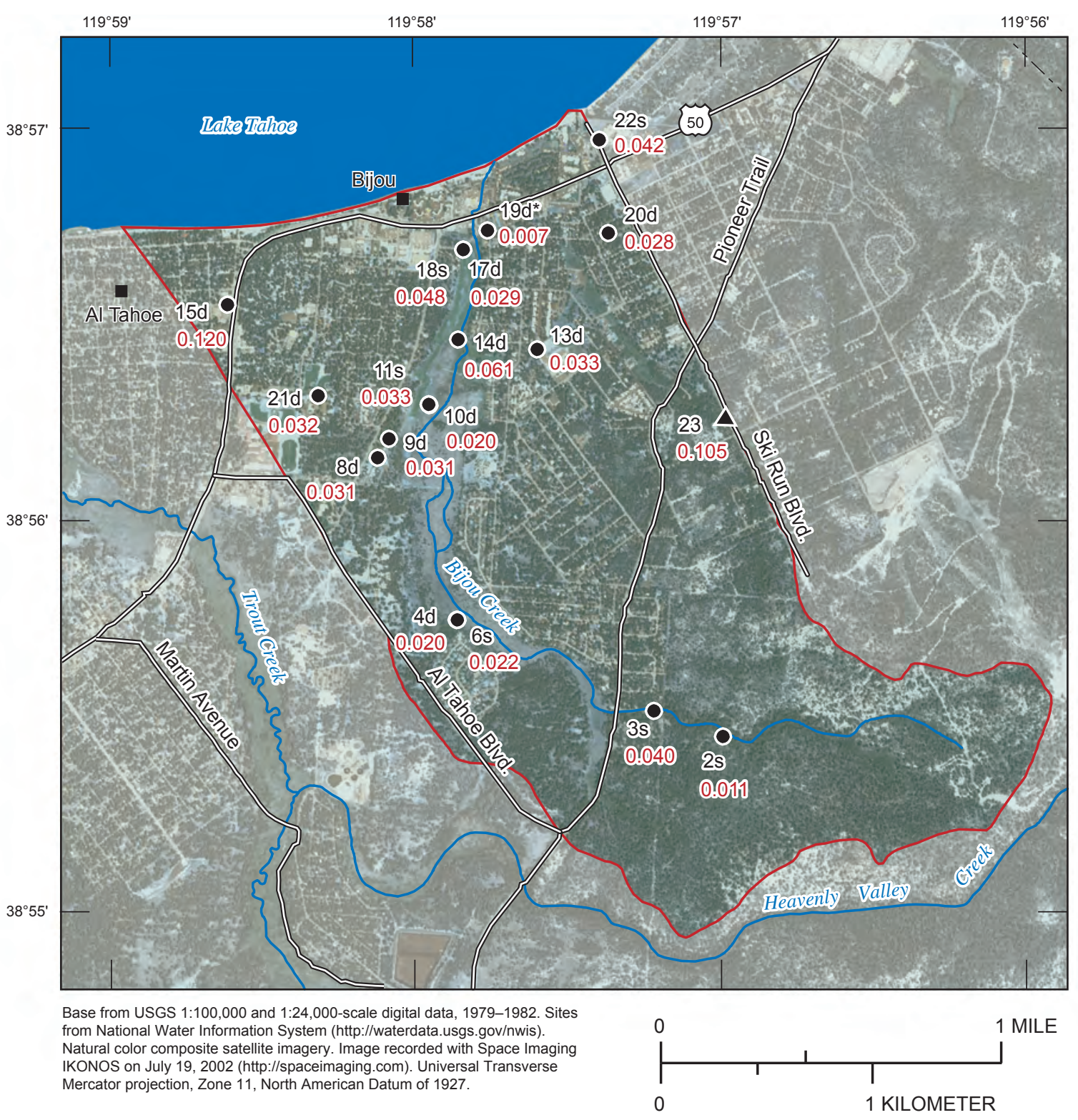

\section{EXPLANATION}

- Study area boundary

Sampling site location-Lower number is ammonia concentration, filtered, in milligrams per liter

21 Ground-water site-Upper number is site number followed by ground-water depth designation (s, less than 18 feet deep; d, greater than or equal to 18 feet deep). Asterisk indicates site sampled in June 2002

23 A Surface-water site-Upper number is site number

Figure 9. Maps showing nutrient concentrations in the Bijou Creek watershed measured during the summer of 2003, for ( $\boldsymbol{A}$ ) ammonia, (B) nitrate, (C) organic nitrogen plus ammonia, (D) orthophosphate, (E) phosphorus, and $(\boldsymbol{F})$ biologically-available iron. 


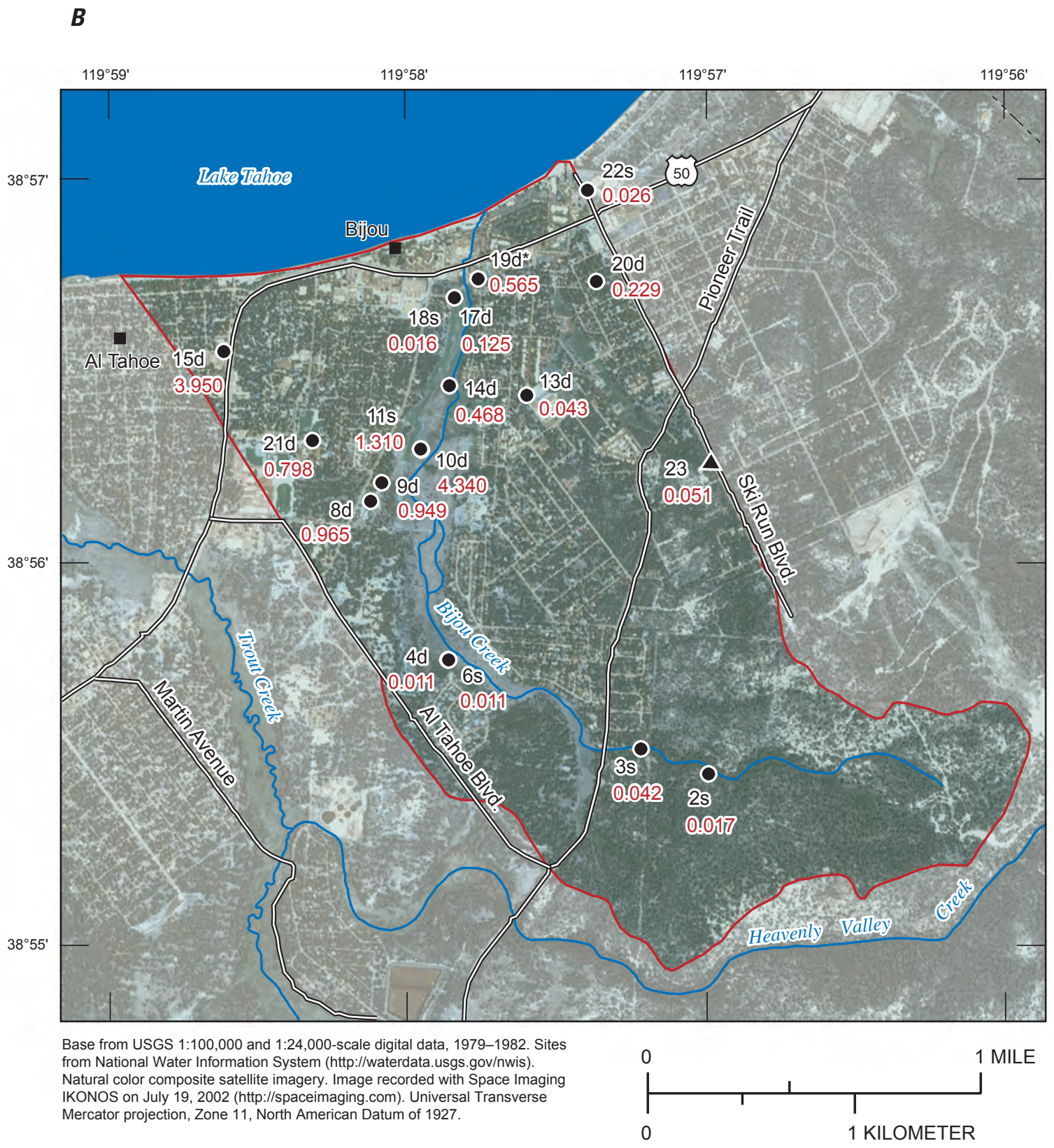

\section{EXPLANATION}

Study area boundary

Sampling site location-Lower number is nitrate concentration, filtered, in milligrams per liter

21 - Ground-water site-Upper number is site number followed by ground-water depth designation (s, less than 18 feet deep; d, greater than or equal to 18 feet deep). Asterisk indicates site sampled in June 2002

23 A Surface-water site-Upper number is site number

Figure 9B. Nitrate 
$\boldsymbol{C}$

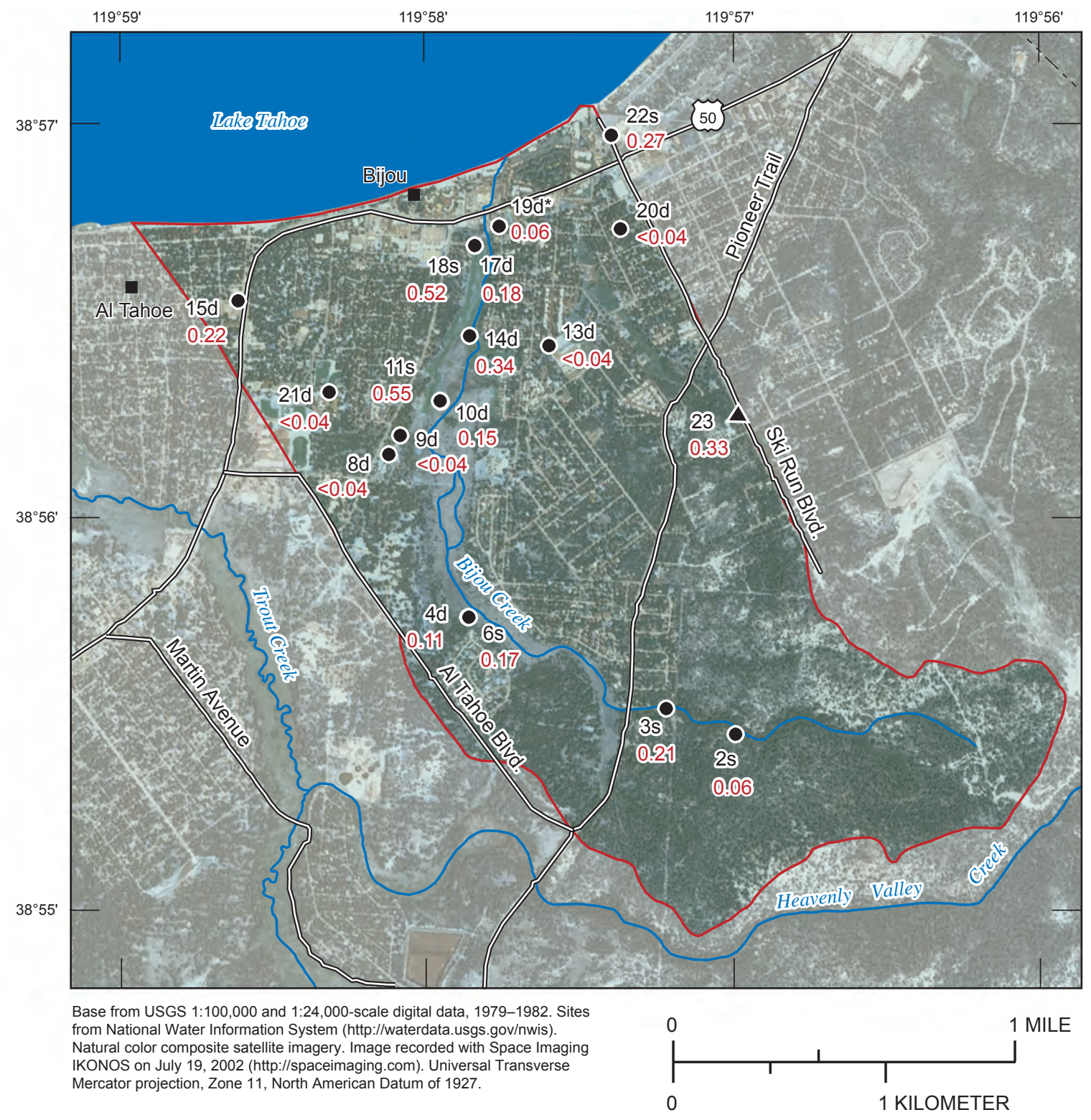

\section{EXPLANATION}

\section{Study area boundary}

Sampling site location-Lower number is organic nitrogen plus ammonia concentration, filtered, in milligrams per liter

21 - Ground-water site-Upper number is site number followed by ground-water depth designation (s, less than 18 feet deep; d, greater than or equal to 18 feet deep). Asterisk indicates site sampled in June 2002

Surface-water site-Upper number is site number

Figure 9C. Organic nitrogen plus ammonia 
D

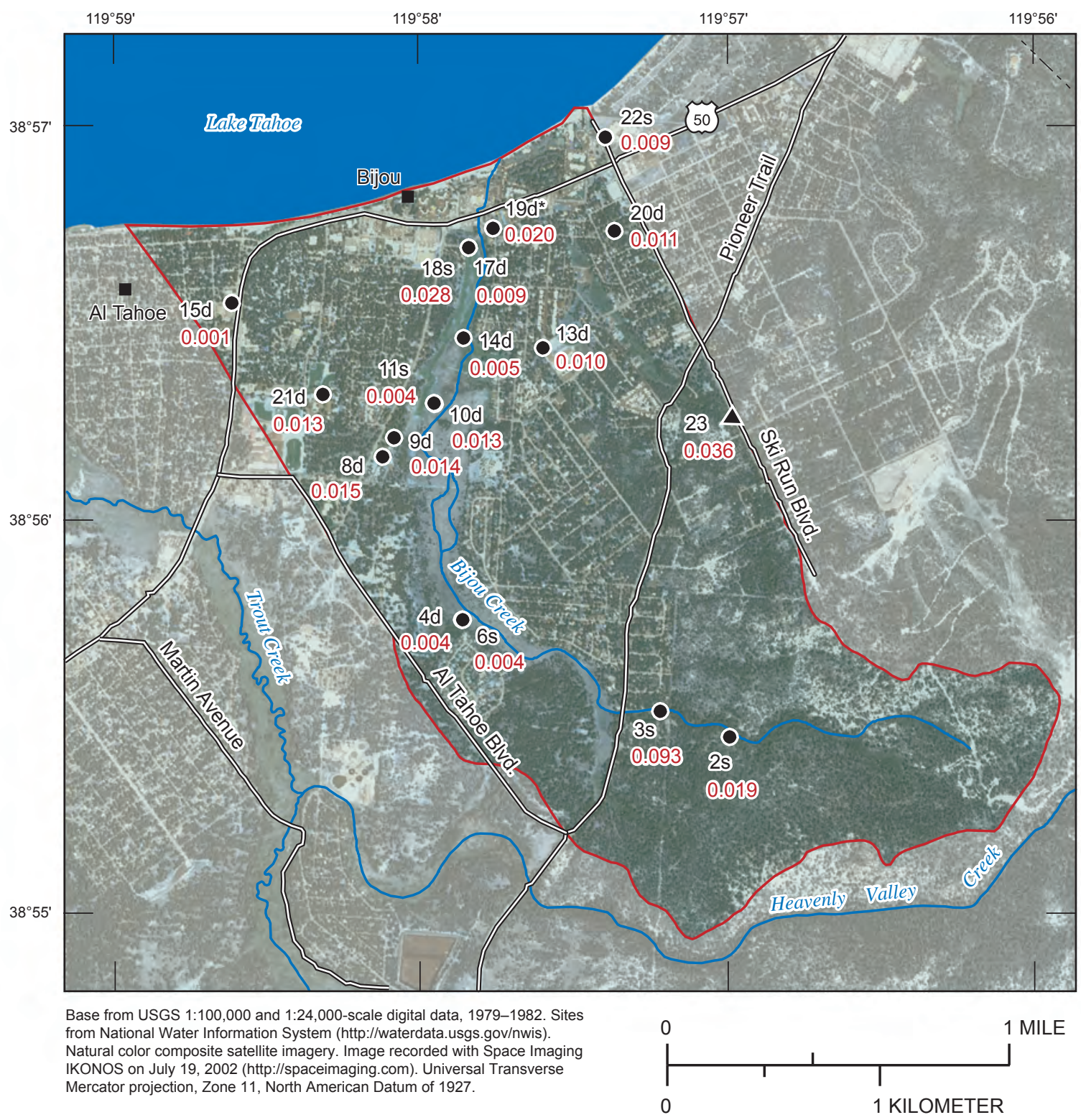

\section{EXPLANATION}

\section{Study area boundary}

Sampling site location-Lower number is orthophosphate concentration, filtered, in milligrams per liter

21 - Ground-water site-Upper number is site number followed by ground-water depth designation (s, less than 18 feet deep; d, greater than or equal to 18 feet deep). Asterisk indicates site sampled in June 2002

23

- Surface-water site-Upper number is site number

Figure 9D. Orthophosphate 


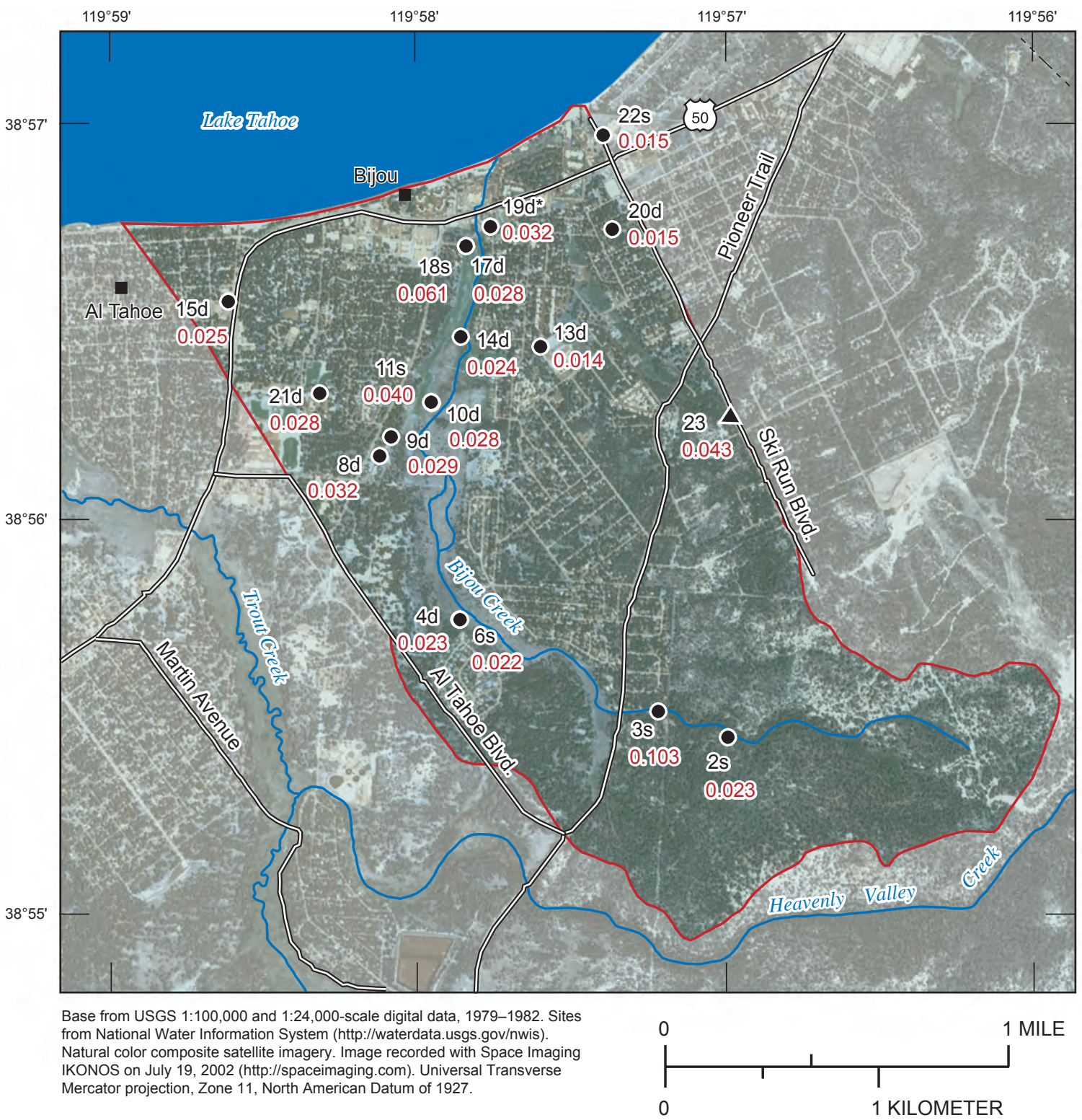

\section{EXPLANATION}

\section{- Study area boundary}

Sampling site location-Lower number is phosphorus concentration, filtered, in milligrams per liter

21 Ground-water site-Upper number is site number followed by ground-water depth designation (s, less than 18 feet deep; d, greater than or equal to 18 feet deep). Asterisk indicates site sampled in June 2002

23

Surface-water site-Upper number is site number

Figure 9E. Phosphorus 


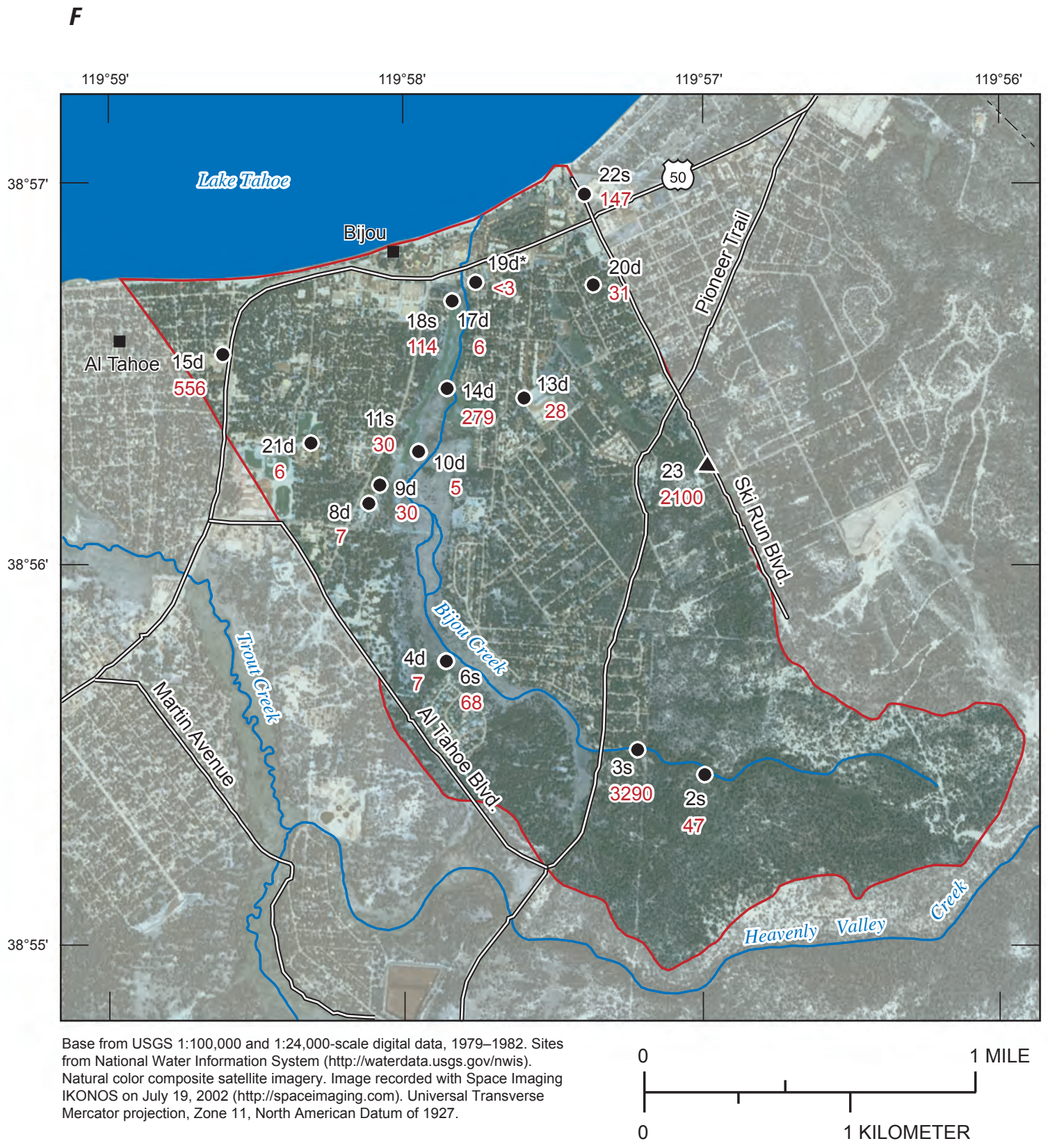

EXPLANATION

- Study area boundary

Sampling site location-Lower number is biologically-available iron concentration, filtered, in milligrams per liter

21 Ground-water site-Upper number is site number followed by ground-water depth designation (s, less than 18 feet deep; d, greater than or equal to 18 feet deep). Asterisk indicates site sampled in June 2002

23 Surface-water site-Upper number is site number

Figure 9F. Biologically-available iron 
variability of $\mathrm{DFe}$ in the Bijou Creek watershed ground water were greater than in the LTIMP ground-water network. DOP and DP concentrations in the deep and shallow ground water of the Bijou Creek watershed did not appear to be different. DFe concentration, however, was generally greater in the shallow ground water than in the deeper ground water.

The data support the hypothesis that $\mathrm{NH}_{4}, \mathrm{NO}_{3}, \mathrm{DKN}$, and DFe concentrations are greater in the Bijou Creek watershed than in the LTIMP ground-water network. The hypothesis was rejected for phosphorus concentrations. DP and DOP concentrations are less in the Bijou Creek watershed than in the LTIMP ground-water network.

Nutrient concentrations and field measurements have been monitored at two sites in the study area since water year 1990. A parametric trend test was applied to this data for parameters without values below the method detection limit. The majority of $\mathrm{NH}_{4}$ and DKN concentrations at these two sites were at or below their method detection limits. Concentrations of $\mathrm{NO}_{3}$ were increasing at one site and undetermined at the other. DOP concentrations were decreasing at one site, and no trend was detected at the other. No trends were detected for DP, DFe, water temperature, and $\mathrm{pH}$ at either site. Specific conductance was increasing at one site and not changing at the other site.

Nutrient concentrations and field-measured parameters had no obvious spatial patterns in their distributions within the study area. Water-level altitudes generally increased with increasing land-surface altitude and were the lowest near Lake Tahoe. All water-level altitudes were greater than the altitude of the surface of Lake Tahoe, except for a single site affected by pumping from production wells. This mostly supports the hypothesis that ground water in the study area flows towards and discharges into Lake Tahoe, except locally where groundwater levels are lowered by nearby pumping.

\section{References Cited}

Adams, K.D., 2004, Shorezone erosion at Lake Tahoe: Historical aspects, processes, and stochastic modeling: Final report for the U.S. Bureau of Reclamation and Tahoe Regional Planning Agency, March 31, 2004, Desert Research Institute, $99 \mathrm{p}$.

Berris, S.N., Crompton, E.J., Joyner, J.D., and Ryan, Rosalyn, 2002, Water Resources Data, Nevada, Water Year 2002:

U.S. Geological Survey Water-Data Report NV-02-1, 600 p.

Bonner, L.J., Evetts, D.M., Swartwood, J.R., and Wilson, J.W., 2004, Water Resources Data, Nevada, Water Year 2004: U.S. Geological Survey Water-Data Report NV-04-1, accessed May 25, 2005 at <http://nevada.usgs.gov/ADR/ index.htm>.
Boughton, C.J., Rowe, T.G., Allander, K.K., and Robledo, A.R., 1997, Stream and ground-water monitoring program, Lake Tahoe Basin, Nevada and California: U.S. Geological Survey Fact Sheet FS-100-97, 6 p.

Cartier, K.D., Peltz, L.A., and Long, Katie, 1995, Hydrologic basins and hydrologic-monitoring sites of Lake Tahoe Basin, California and Nevada: U.S. Geological Survey Open-File Report 95-316, 1 sheet.

Crippen, J.R., and Pavelka, B.R., 1970, The Lake Tahoe Basin, California - Nevada: U.S. Geological Survey Water-Supply Paper 1972, 56 p.

Goldman, C.R., 1988, Primary productivity, nutrients, and transparency during the early onset of eutrophication in ultra-oligotrophic Lake Tahoe, California-Nevada: Limnology and Oceanography, v. 33, no. 6, p. 1321-1333.

Goldman, C.R., 2000, Baldi Lecture; Four decades of change in two subalpine lakes: Verhandlungen der Internationale Vereinigung fur Theoretische und Angewandte Limnologie, v. 27 , p. $7-26$.

Hunter, D.A., Reuter, J.E., and Goldman, C.R., 1993, Standard operating procedures-Lake Tahoe Interagency Monitoring Program: Tahoe Research Group, University of California, Davis, $79 \mathrm{p}$.

Jorgensen, L.N., Seacer, A.L., and Kaus, S.J., 1978, Hydrologic basins contributing to outflow from Lake Tahoe, California-Nevada: U.S. Geological Survey Hydrologic Investigations Atlas HA - 587, 1 sheet.

Loeb, S.L., 1987, Groundwater quality within the Tahoe Basin: University of California, Davis, 265 p.

Loeb, S.L., Aloi, J.E., and Hackley, S.H., 1986, Littoral zone investigations, Lake Tahoe 1982-1985-Periphyton: University of California, Davis, 158 p.

Reuter, J.E., and Miller, W.W., 2000, Aquatic resources, water quality, and limnology of Lake Tahoe and its upland watershed, in Lake Tahoe Watershed Assessment, Murphy, D.D., and Knopp, C.M., eds.: U.S. Department of Agriculture, Forest Service, General Technical Report, PSW-GTR-175, p. 213-399.

Reuter, J.E., Jassby, A.D., Marjanovic, P., Heyvaert, A.C., and Goldman, C.R., 1998, Preliminary phosphorous and nitrogen budgets for Lake Tahoe, Annual Progress Report1998: Lake Clarity and watershed modeling, Presidential deliverable: Tahoe Research Group, Department of Civil and Environmental Engineering, John Muir Institute for the Environment, University of California, Davis, 28 p. 
Rowe, T.G., and Allander, K.K., 2000, Surface- and groundwater characteristics in the Upper Truckee River and Trout Creek Watersheds, South Lake Tahoe, California and Nevada, July-December 1996: U.S. Geological Survey Water-Resources Investigations Report 00-4001, 39 p.

Scott, V.H., Scalmani, J.C., and Matthews, R.A., 1978, Groundwater resources of the South Tahoe Public Utility District: University of California, Davis, Water Science and Engineering Papers, no. 2007, 62 p.

Stockton, E.L., Jones, C.Z., Rowland, R.C., and Medina, R.L., 2003, Water Resources Data, Nevada, Water Year 2003: U.S. Geological Survey Water-Data Report NV-03-1, 679 p.

Tahoe Regional Planning Agency and U.S. Forest Service, 1971, Geology and Geomorphology of the Lake Tahoe Region-A guide for planning: South Lake Tahoe, Calif. $59 \mathrm{p}$.

Taylor, Kendrick, 2002, Investigation of near shore turbidity at Lake Tahoe: Desert Research Institute, Division of Hydrologic Sciences Publication no. 41179, 22 p.

Taylor, Kendrick; Susfalk, Rick; Shanafield, Margaret; and Schladow, Geoff, 2004, Near-shore clarity at Lake Tahoe: Status and causes of reduction: Desert Research Institute, Division of Hydrologic Sciences Publication no. 41193, $80 \mathrm{p}$.
Thodal, C.E., 1997, Hydrogeology of Lake Tahoe Basin, California and Nevada, and results of a ground-water quality monitoring network, water years 1990-92: U.S. Geological Survey Water-Resources Investigations Report 97-4072, $53 \mathrm{p}$.

Thomas, James; Mihevc, Todd; Cooper, Clay; Gunter, Melissa; Heyvaert, Alan; and Michalski, Gregory, 2004, Groundwater nutrient loading to Lake Tahoe in a near-shore area with high turbidity and chlorophyll: Desert Research Institute, Division of Hydrologic Sciences Publication no. $41213,18 \mathrm{p}$.

U.S. Army Corps of Engineers, 2003, Lake Tahoe Basin framework study groundwater evaluation: Lake Tahoe Basin, Calif. and Nev., October 2003.

Wilde, F.D., Radtke, D.B., Gibs, Jacob, and Iwatsubo, R.T., eds., 1999, National Field Manual for Collection of waterquality data: Collection of water samples: U.S. Geological Survey Techniques of Water-Resources Investigations, book 9, chap. A4, accessed May 25, 2005 at <http://water.usgs. gov/owq/FieldManual/chapter4/html/Ch4_contents.html $>$. 
